Article

\title{
Analysis of the Technological Evolution of Materials Requirements Included in Reactor Pressure Vessel Manufacturing Codes
}

\author{
Alvaro Rodríguez-Prieto ${ }^{1, *(0)}$, Mariaenrica Frigione ${ }^{2}\left(\mathbb{D}\right.$, John Kickhofel ${ }^{3}\left(\mathbb{C}\right.$ and Ana M. Camacho ${ }^{1}(\mathbb{D}$ \\ 1 Department of Manufacturing Engineering, Universidad Nacional de Educación a Distancia (UNED), \\ 28040 Madrid, Spain; amcamacho@ind.uned.es \\ 2 Department of Engineering for Innovation, University of Salento, Prov. le Lecce-Monteroni, 73100 Lecce, Italy; \\ mariaenrica.frigione@unisalento.it \\ 3 Apollo Plus, 7 Weineggstrasse, 8008 Zurich, Switzerland; jkickhofel@apolloplus.com \\ * Correspondence: alvaro.rodriguez@ind.uned.es; Tel.: +34-913-988-660
}

Citation: Rodríguez-Prieto, A.; Frigione, M.; Kickhofel, J.; Camacho, A.M. Analysis of the Technological Evolution of Materials Requirements Included in Reactor Pressure Vessel Manufacturing Codes. Sustainability 2021, 13, 5498. https://doi.org/ $10.3390 /$ su13105498

Academic Editor: Michael I. Ojovan

Received: 20 April 2021

Accepted: 10 May 2021

Published: 14 May 2021

Publisher's Note: MDPI stays neutral with regard to jurisdictional claims in published maps and institutional affiliations.

Copyright: (c) 2021 by the authors. Licensee MDPI, Basel, Switzerland. This article is an open access article distributed under the terms and conditions of the Creative Commons Attribution (CC BY) license (https:// creativecommons.org/licenses/by/ $4.0 /)$.

\begin{abstract}
The growth of green energy technologies within the frame of the 7th Sustainable Development Goal (SDG) along with the concern about climatic changes make nuclear energy an attractive choice for many countries to ensure energy security and sustainable development as well as to actively address environmental issues. Unlike nuclear equipment (immovable goods), which are often well-catalogued and analyzed, the design and manufacturing codes and their standardized materials specifications can be considered movable and intangible goods that have not been thoroughly studied based on a detailed evaluation of the scientific and technical literature on the reactor pressure vessel (RPV) materials behavior. The aim of this work is the analysis of historical advances in materials properties research and associated standardized design codes requirements. The analysis, based on the consolidated U.S. Nuclear Regulatory Commission (NRC) Regulatory Guide (RG) 1.99 Rev.2 model, enables determination of the best materials options, corresponding to some of the most widely used material specifications such as WWER 15Kh2MFAA (used from the 1970s and 1980s; already in operation), ASME SA-533 Grade B Cl.1 (used in pressurized water reactor-PWR 2nd-4th; already in operation), DIN 20MnMoNi55 and DIN 22NiMoCr37 (used in PWR 2nd-4th) as well as ASTM A-336 Grade F22V (current designs). Consequently, in view of the results obtained, it can be concluded that the best options correspond to recently developed or well-established specifications used in the design of pressurized water reactors. These assessments endorse the fact that nuclear technology is continually improving, with safety being its fundamental pillar. In the future, further research related to the technical heritage from the evolution of materials requirements for other clean and sustainable power generation technologies will be performed.
\end{abstract}

Keywords: technology; technological advancements; technical heritage; materials science; requirement; degradation; irradiation embrittlement; reactor pressure-vessel; manufacturing code

\section{Introduction}

The 7th Sustainable Development Goal (SDG), as established by the United Nations for 2030, aims to ensure access to a reliable, sustainable, affordable and modern energy. This issue, along with the growing concern about climatic changes, has provided the impetus required for the growth of green energy technologies. In this context, nuclear energy is a meaningful option, as it is a nearly carbon-free source of power, evaluated over its entire lifecycle [1]. Thus, nuclear power is the choice of many countries to ensure energy security and sustainable development as well as actively addressing environmental issues [2]. Our societies face a tremendous and increasing energy need while needing to mitigate global climate change and preserve the environment [3]. The development of nuclear reactors has followed an evolutionary track of both the technical solution and the questions the 
technology is trying to address [4]. Even though accidents at nuclear power plants (NPPs) have potentially devastating consequences, they cannot be completely removed from the current energy portfolio because nuclear power has the smallest full-lifecycle carbon footprint among all energy sources and is one of the cheapest available energy sources $[5,6]$. In summary, nuclear power is a promising solution to meet worldwide increasing demand for energy, to limit the consumption of non-renewable resources for producing energy and to reduce $\mathrm{CO}_{2}$ emissions. Many key industrial and scientific processes, such as the generation of nuclear energy, are of enormous social benefit as energy demand and consumption grow over time [7]. In addition, nuclear applications of combined cycles have been the subjects of a recent investigation [8], including small modular reactors (SMRs) [9] and high-temperature reactors for combined electricity/hydrogen production [10]. Safety is the most important aspect to consider in the design and construction stages of a nuclear power plant. Although there are many aspects of reactor safety, the safe operation of a nuclear reactor ultimately hinges on the structural integrity of the components [11]. Reactor pressure vessel (RPV) steels play a critical role in the operation safety of any nuclear power plant. Within a nuclear power plant, there are many components made of steel, such as pipes or high-pressure vessels, in areas subjected to radiation [12,13]. Thus, from this perspective, the most important structural component of a nuclear power plant is the RPV, which is constructed primarily from ferritic steels that have to meet specific requirements in terms of impurity contents $[14,15]$. Structural materials are key to the containment of nuclear fuel and fission products as well as reliable and thermodynamically efficient production of electrical energy from nuclear reactors. High-performance metallic structural materials will be critical for the future success of proposed fusion energy reactors, which will expose the structures to unprecedented fluxes of high-energy neutrons along with intense thermomechanical stresses [16].

Nowadays, regulations on nuclear and radiological safety tend to be homogenized in all countries of the world; however, they do not reach the same legal formulation, since this is the competence of national parliament legislations. This means that at present there are still serious differences in the nuclear regulations of some countries and therefore in the technological requirements for the manufacture of main components, which are the result of the historical vicissitudes experienced since the beginning of the nuclear age [17]. For this reason, to ensure its safety function, the manufacture and in-service inspection of reactor vessels is carried out according to specific codes or standards; among these are the ASME B\&PV code (USA), the-AFCEN codes (France), KTA standards (Germany), GOST standards (Russia), and the JSME code (Japan), to ensure suitable quality and safety. There are several design code possibilities in pressure vessel manufacturing, which is important because engineers must assess the standards early in the design process, at which point some key parameters may still be uncertain $[18,19]$. The success of nuclear energy relies on materials which provide and sustain a host of high-performance properties [20]. RPV steels must satisfy standard materials design criteria based mainly on an adequate resistance to radiation damage and chemical degradation. In addition, nuclear applications must also consider the nuclear physics characteristics of materials. This additional restriction in nuclear materials engineering poses tremendous challenges but also opportunities in material advancements [21]. We distinguish two main types of degradation mechanisms in steel components that operate in a nuclear reactor environment [22]:

- Corrosion of materials and corrosion erosion, stress corrosion and corrosion-fatigue combined processes;

- Embrittlement by irradiation of the steels of the vessel.

The irradiation embrittlement of RPV ferritic steels is the most influential aging mechanism affecting PWR reactor pressure vessels [14,23].

The Spanish National Plan for Industrial Heritage includes the analysis of goods in three categories: immovable, movable and intangible. Nuclear heritage includes the life cycle of nuclear technology, ranging from its intellectual conception, defining the design requirements, to its testing, implementation, operation and decommissioning. 
While all nuclear equipment (immovable) is often well-catalogued and analyzed, design and manufacturing codes and their standardized material specifications (movable and intangible) have not been thoroughly studied based on a detailed evaluation of the scientific and technical literature on the behavior of RPV materials. Thus, the aim of this work is the study of the historical advances on materials properties research and their associated standardized design codes requirements, based on a novel methodology of analysis that combines an extensive technological and scientific literature review with the application of a standardized prediction model. Consequently, more than 80 historical research works have been analyzed in this study, reported in more than 20 books related to radiation effects on reactor pressure vessels. They have been reviewed to draw general conclusions on the behavior of the materials most used in the manufacture of RPV and on their technical specifications.

\section{Methodology}

The methodology of the performed analysis is divided into 3 stages (Figure 1).

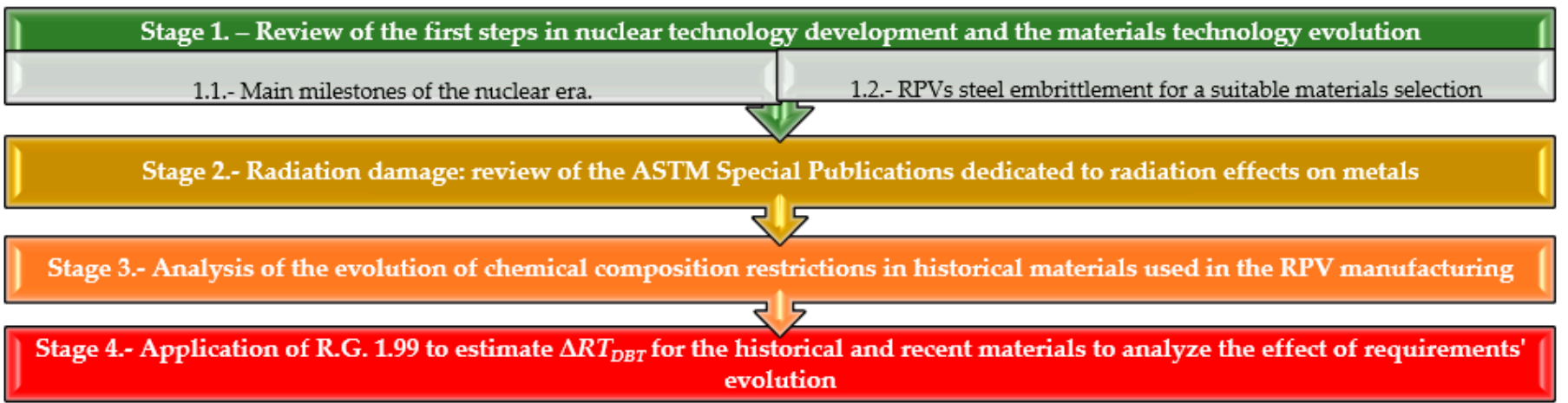

Figure 1. Stages of the methodology.

- Stage 1. Review of the first steps in nuclear technology development and the materials technology evolution: main milestones of the nuclear era (Section 2.1.1) and review of contemporary data and theory regarding RPV steel embrittlement for a suitable materials selection (Section 2.1.2).

- Stage 2. Radiation damage: review of the ASTM Special Publications dedicated to radiation effects on metals.

- Stage 3. Analysis of the evolution of chemical composition restrictions in historical materials used in the RPV construction.

- Stage 4. Application of U.S. NRC R.G. 1.99 to estimate ductile-to-brittle transition temperature $\left(\triangle R T_{D B T}\right)$ for both historical and contemporary materials to analyze the effect of the requirements' evolution.

\subsection{Stage 1.--Review of the First Steps in Nuclear Technology Development and Materials Technology Evolution}

This stage of the methodology provides a review of the main milestones of the civil nuclear era (Section 2.1.1) and a review of the state of the art of the RPVs steel embrittlement for a suitable materials selection (Section 2.1.2).

\subsubsection{Main Milestones of the Nuclear Era}

In 1938, it was confirmed that the nucleus of an atom could actually be split in two (fission) and the fission of an atom resulted in a release of energy; subsequently, nuclear power generation became feasible. Important milestones in the history of nuclear technology and energy are shown in Table 1. 
Table 1. Main milestones of the nuclear technological era [24,25].

\begin{tabular}{|c|c|c|}
\hline Chronology & Description & Type \\
\hline 1939 January & $\begin{array}{c}\text { Otto Hahn and Fritz Strassman report in the journal Naturwissenschaften that they have bombarded and split the } \\
\text { uranium atom into two or more lighter elements. }\end{array}$ & • \\
\hline 1942 December & The first self-sustaining nuclear chain reaction occurs at the University of Chicago. & • \\
\hline 1946 August & $\begin{array}{c}\text { The Atomic Energy Act of } 1946 \text { creates the Atomic Energy Commission (AEC) to control nuclear energy development } \\
\text { and explore peaceful uses of nuclear energy. }\end{array}$ & $\circ$ \\
\hline 1951 December & In Arco, Idaho, Experimental Breeder Reactor I produces electric power, lighting four light bulbs. & - \\
\hline 1953 March & Nautilus starts its nuclear power units for the first time. & • \\
\hline 1953 December & President Eisenhower delivers his "Atoms for Peace" speech before the United Nations. & ○ \\
\hline 1954 August & President Eisenhower signs The Atomic Energy Act of 1954, the first major amendment of the original Act. & ○ \\
\hline 1955 January & The AEC announces the Power Demonstration Reactor Program. & ○ \\
\hline 1955 July & Arco, Idaho, population 1000 , becomes the first town powered by a nuclear powerplant. & • \\
\hline 1955 August & Geneva (Switzerland) hosts the first United Nations International Conference on the Peaceful Uses of Atomic Energy. & ○ \\
\hline 1957 July & The first power from a civilian nuclear unit is generated by the Sodium Reactor Experiment at Santa Susana, California. & - \\
\hline 1957 October & $\begin{array}{c}\text { The United Nations creates the International Atomic Energy Agency (IAEA) in Vienna, Austria, to promote the peaceful } \\
\text { use of nuclear energy. }\end{array}$ & $\circ$ \\
\hline 1957 December & $\begin{array}{c}\text { The world's first large-scale nuclear powerplant begins operation in Shippingport, Pennsylvania. The plant reaches full } \\
\text { power three weeks later and supplies electricity to the Pittsburgh area. }\end{array}$ & $\bullet \circ$ \\
\hline Early 1960s & $\begin{array}{l}\text { Small nuclear power generators are first used in remote areas to power weather stations and to light buoys for } \\
\text { sea navigation. }\end{array}$ & • \\
\hline 1961 November & $\begin{array}{l}\text { The U.S. Navy commissions the world's largest ship, the U.S.S. Enterprise (nuclear-powered aircraft carrier with the } \\
\text { ability to operate for up to } 740,800 \mathrm{~km} \text { without refueling). }\end{array}$ & $\bullet$ \\
\hline 1965 April & The first nuclear reactor in space (SNAP-10A) is launched by the United States. & • \\
\hline 1970 March & $\begin{array}{l}\text { The United States, United Kingdom, Soviet Union and } 45 \text { other nations ratify the Treaty for Non-Proliferation of } \\
\text { Nuclear Weapons. }\end{array}$ & $\circ$ \\
\hline 1974 October & $\begin{array}{l}\text { The Energy Reorganization Act of } 1974 \text { divides AEC functions in two new agencies: Energy Research and Development } \\
\text { Administration (ERDA), to carry out research; and Nuclear Regulatory Commission (NRC), to regulate nuclear power. }\end{array}$ & $\circ$ \\
\hline 1977 October & Department of Energy (DOE) begins operations. & $\circ$ \\
\hline 1979 March & $\begin{array}{l}\text { The worst accident in U.S. commercial reactor history occurs at the Three Mile Island nuclear power station near } \\
\text { Harrisburg, Pennsylvania. The accident was caused by a loss of coolant from the reactor core due to a combination of } \\
\text { mechanical malfunction and human error. }\end{array}$ & $\diamond$ \\
\hline
\end{tabular}

DOE initiates the Three Mile Island accident research and development program to develop technology for

1980 March disassembling and de-fueling the damaged reactor. The program continued for 10 years and made significant advances in developing new nuclear safety technology.

\begin{tabular}{|c|c|c|}
\hline 1986 April & $\begin{array}{l}\text { Operator error causes two explosions at the Chernobyl No. } 4 \text { nuclear powerplant in the former Soviet Union. The } \\
\text { reactor has an inadequate containment building, and large amounts of radiation escape. A plant of such design would } \\
\text { not be licensed in the United States or Western Europe. }\end{array}$ & $\diamond$ \\
\hline 1989 April & $\begin{array}{c}\text { The NRC proposes a plan for reactor design certification, early site permits, and combined construction and } \\
\text { operating licenses. }\end{array}$ & - ० $\diamond$ \\
\hline 1990 March & $\begin{array}{c}\text { DOE launches a joint initiative to improve operational safety practices at civilian nuclear powerplants in the former } \\
\text { Soviet Union. }\end{array}$ & $\circ \diamond$ \\
\hline 2000 December & The last of the reactors at the Chernobyl nuclear power plant are shut down. & $\diamond$ \\
\hline Early 2004 & The first of the late third-generation units was ordered for Finland-a 1600 MWe European PWR (EPR). & $\bullet$ \\
\hline 2011 March & $\begin{array}{l}\text { Fukushima Daiichi nuclear power plant accident occurs after a severe earthquake off the coast of Japan. This caused the } \\
\text { establishment of more stringent safety specifications for reactors around the world. }\end{array}$ & $\diamond$ \\
\hline 2020 July & ITER begins its assembly with the support of 35 countries. & • \\
\hline
\end{tabular}

Note about the type of milestone: Technology $\rightarrow \bullet$; Regulation and Public dissemination $\rightarrow \circ$; Failures, accidents and learned lessons $\rightarrow \diamond$.

Among the reactors cooled by light water, the most interesting currently are those of the pressurized water type (Pressure Water Reactor, PWR) and those of boiling water type (Boiling Water Reactor, BWR). Henceforth, we will focus on PWR-type reactor vessels, as they are the most widely used technology in reactors currently operating in the global 
nuclear fleet [26]. Currently, 301 of the 441 reactors in operation are PWR-type. Figure 2 provides an overview of the main generations of PWR technology.

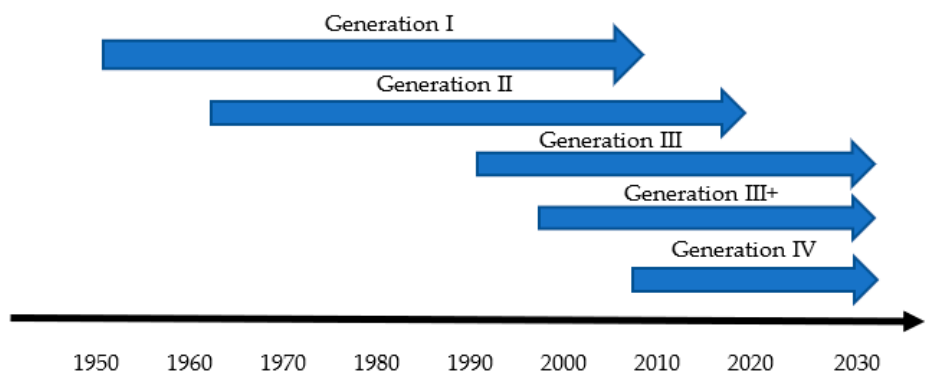

Figure 2. Generations of PWR technology.

RPVs are made up of a cylindrical body affixed to a hemispherical bottom and lid. The body and hemispheres are made up of rings that in turn are made up of curved and vertically welded sheets, although in some of the more recently manufactured vessels there has been an attempt to avoid welding by forging complete pieces. The probability that the vessel suffers a catastrophic failure based on the analytical approach proposed in the official publication NUREG/CR-5750 [27], when it has been manufactured in accordance with guidelines specified in proper codes, and in the absence of failures caused by an improper selection of materials, is less than 1 in 4,000,000 during each year of operation of the reactor. If we consider a useful life of 40 years, the catastrophic failure probability is 1 in 100,000 throughout the operation of the facility. If we consider the more than 400 reactors currently operating around the world, the probability of an event of this type taking place would be lower than 1 in 250, that is, lower than $0.4 \%$ [17]. Nevertheless, it is important to control the manufacturing process to avoid cases like the Doel III and Tihange II NPPs where cracks were detected in the reactor vessels that led to their temporary shutdown. These issues may have been due to some error made in the design (including the material selection stage) manufacturing process of the vessel. It is worth noting that, in the case of pressurized water reactors (PWR), steels employed to build components for the primary circuit of a nuclear power plant should be able to withstand temperatures of $300{ }^{\circ} \mathrm{C}$ and an internal pressure of around $18 \mathrm{MPa}$, in addition to high doses of radiation [13].

2.1.2. Review of the State of the Art of the RPVs Steel Embrittlement for Suitable Materials Selection

History of Irradiation Embrittlement Understanding. Identifying the Role of Different Parameters Since the Earliest Steps

Materials of RPVs are exposed to neutron radiation generated by nuclear fission reactions and can experience considerable damage even at very low doses of radiation, causing embrittlement and a shift of the $\triangle R T_{D B T}$. Nanoscale microstructures induced by irradiation obstruct the migration of dislocations. This interaction prevents plastic deformation and induces steel embrittlement [28]. Neutron irradiation degrades the mechanical properties of RPV steels and the extent of the degradation is determined by the type and structure of the steel as well as by other factors, such as neutron fluence, irradiation temperature, neutron flux and chemical composition [29].

A comprehensive explanation of radiation damage in solids was first given by Wigner more than a half century ago [30]. In the case of PWR RPVs, damage is produced mostly by fast neutrons $(\mathrm{E} \approx 0.1$ to $15 \mathrm{MeV})$ in the RPV wall at the height of core [31]. On the basis of Seitz's theory [32,33], collisions occur between neutrons and lattice atoms and between displaced and lattice atoms. If sufficient energy is transmitted during a collision, the impacted atom will be displaced from its site and knocked into an interstitial position. The effect of irradiation on elastic constants was firstly determined by Charlesby, Hancock and Sansom in 1954 [34]. In the same year, Wilson and Berggren [35] irradiated specimens 
of ASTM-A212 Gr. B steel at temperatures lower than $50{ }^{\circ} \mathrm{C}$ and verified an increase in the $\triangle R T_{D B T}$.

Under typical operating conditions in a nuclear reactor, chemical composition is more influential on the process of neutron irradiation embrittlement than neutron flux [36] and irradiation temperature [37,38]. Mager [38] did not find apparent dependence between the neutron flux value and the embrittlement of the material, for neutron flux rates from $\phi=2.5 \times 10^{18} \mathrm{n} / \mathrm{cm}^{2}$ to $\phi=8.8 \times 10^{19} \mathrm{n} / \mathrm{cm}^{2}$. Porter [36] and Kangilaski [37] determined that the irradiation temperature for which the embrittlement of the material is maximum takes place at temperatures below $230{ }^{\circ} \mathrm{C}$. Pachur [39] showed that an irradiation temperature of $150{ }^{\circ} \mathrm{C}$ produces the greatest fragility of the material. This is because an increase in the irradiation temperature favors the repair of defects produced by neutron bombardment, through a process of annealing the material [14]. Figure 3 provides these main contributions to material embrittlement, highlighting the role of chemical composition.

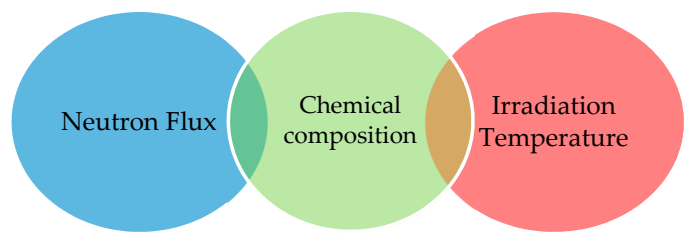

Figure 3. Main contributions that enhance the radiation embrittlement susceptibility of steels.

These studies on the influence of the chemical composition, neutron flux and irradiation temperature, under operating conditions of nuclear reactors are considered still valid today since they have been confirmed by analyzing the materials from reactors that have been in operation for decades [40-43]. Therefore, nowadays, it is a proven fact that the effect of neutron flux on the brittle-ductile behavior of the material is a complex phenomenon dependent on the composition of the alloy and on temperature [44].

Main Technological Characteristics Influencing Irradiation Embrittlement Characteristics

The weight percentages of copper, phosphorus and nickel are important parameters in RPV steels [45], the first two being the ones that most affect irradiation embrittlement. Copper-rich precipitates, which act as barriers to the dislocation motion on the slip plane, have been recognized as contributing to radiation hardening in irradiated alloys [46]. A model analysis for $\mathrm{Cu}$-rich precipitates and an empirical logarithmic law for relaxation of residual stress demonstrated that an increment of the embrittlement due to $\mathrm{Cu}$-rich precipitates increases with $\mathrm{Cu}$ and $\mathrm{Ni}$ contents and is proportionate to yield stress change, which is related to irradiation hardening [47]. In 1996, Odette et al. [48] concluded that a Cu wt. $\%$ content greater than $0.1 \mathrm{wt} . \%$ generates copper-rich precipitates that are responsible for irradiation embrittlement of nuclear primary loop materials. Odette et al. studied the influence of $\mathrm{Cu}$ wt.\% in twenty-two samples with different concentrations of this element, irradiated with a neutron flux between $\phi=0.76 \times 10^{16} \mathrm{n} / \mathrm{cm}^{2}$ and $\phi=7.1 \times 10^{22} \mathrm{n} / \mathrm{cm}^{2}$ (this range includes the neutron flux $\phi=5 \times 10^{19} \mathrm{n} / \mathrm{cm}^{2}$ used in material monitoring programs according to the KTA 3203 standard), at temperatures between 260 and $315^{\circ} \mathrm{C}$. Odette et al. concluded that for $\mathrm{Cu}$ levels below $0.1 \%$, copper-rich precipitates responsible for radiation hardening in materials generating a shift of the ductile-to-brittle transition temperature $\left(\triangle R T_{D B T}\right)$ are not formed. When the $\mathrm{Cu}$ wt. $\%$ content is greater than $0.1 \%$, the increase in the $\triangle R T_{D B T}$ due to embrittlement by irradiation is greater the higher the $\mathrm{Cu}$ wt.\% content, verifying that it shows a linear behavior with the $\mathrm{Cu}$ content up to a value between 0.25 and $0.3 \%$ [49]. Specifically, it has been proven that, under the operating conditions of nuclear reactors, ultrafine $\mathrm{Cu}$ precipitates formed within the materials are responsible for radiation-induced embrittlement [50]. Likewise, in these types of steels with Ni content (MnMoNi steels), the precipitates that are formed have been shown experimentally [51] to not contribute to the over-aging or softening of the material. Ni increases the volume and action of $\mathrm{Cu}$ precipitates [49]. Some research works, such as those of Petrequin et al. [52], 
Stofanak et al. [53] and Nikolaeva et al. [54], concluded that, for values lower than $1 \%$ of $\mathrm{Ni}$, no negative effects are observed on the mechanical properties of materials [14].

In addition, it has been experimentally demonstrated that a P wt.\% content greater than $0.02 \mathrm{wt} . \%$ negatively affects the mechanical properties of the material because it increases the brittleness of the material at higher temperatures. For similar irradiation conditions (neutron flux interval between $\phi=1 \times 10^{19} \mathrm{n} / \mathrm{cm}^{2}$ and $\phi=5 \times 10^{20} \mathrm{n} / \mathrm{cm}^{2}$, covering the interval according to KTA 3203 [55]) and temperature $\left(340-460{ }^{\circ} \mathrm{C}\right)$, it has been experimentally assessed how the P wt.\% content (from a threshold of $0.02 \%$ ) negatively affects the mechanical properties of the material, increasing the fragility of the material at higher temperatures. Table 2 provides typical thresholds (maximum allowable wt. $\%$ ) for $\mathrm{Cu}, \mathrm{P}$ and $\mathrm{Ni}$.

Table 2. Chemical composition thresholds (upper limits) of $\mathrm{Cu}, \mathrm{P}$ and Ni.

\begin{tabular}{cc}
\hline Chemical Element & Established Scientific Threshold (Maximum wt.\%) \\
\hline $\mathrm{Cu}$ & 0.10 \\
$\mathrm{P}$ & 0.02 \\
$\mathrm{Ni}$ & 1.00 \\
\hline
\end{tabular}

The irradiation embrittlement has been observed for a temperature range from $340{ }^{\circ} \mathrm{C}$ to $460^{\circ} \mathrm{C}$, so the experimental limit is relevant according to the reactor operating temperature range, between $290^{\circ} \mathrm{C}$ and $350{ }^{\circ} \mathrm{C}$ [56]. Other chemical elements in the composition influence the mechanical properties [57] making it necessary to reduce wt.\% of pernicious elements at minimum. Specifically, Si and V have more influence on irradiation embrittlement susceptibility.

- Regarding $\mathrm{Si}$, it is necessary to keep the silicon content to a minimum [58] to obtain adequate material toughness, because the presence of silicon influences the ductilebrittle transition temperature $\left(\triangle R T_{D B T}\right)[59]$.

- Vanadium, $V$, increases the susceptibility of the material to neutron irradiation embrittlement [60] and decreases the weldability of the steel.

Another element of the alloy that could affect the irradiation embrittlement susceptibility is manganese $(\mathrm{Mn})$ : its presence improves the mechanical properties of steels. Consequently, it is usually added in amounts greater than 1\% [61] but smaller than 3\%. It is important to highlight that the presence of manganese reduces the influence that the material's manufacturing method (forging or lamination) has on its behavior against neutron irradiation [62]. Mn content is similar between the different standardizations analyzed.

There are numerous databases that show results obtained in the monitoring programs of the mechanical properties of vessel steels, some of them are PR-EDB, IAEA-International Database on RPV Materials, Web-enabled database of JRC-EC, ASTM E 10.02, JEAC42012004 and ASTM E900-02 [19]. Likewise, there are numerous standards and material specifications, as well as research papers, technical reports and regulatory guides approved by the Nuclear Regulatory Commission (NRC), the use of which in the selection stage of materials for the vessel is essential to ensure the structural integrity and an adequate mechanical behavior of the material against neutron irradiation.

\subsection{Stage 2.-Radiation Damage: Review of the ASTM SPECIAL Publications Dedicated to Radiation Effects on RPV Metals}

The increase in brittle-ductile transition temperature with neutron exposure is of considerable importance in the selection of materials for nuclear reactor pressure vessels [63]. In the process of radiation damage, the transfer of neutron energy to the nuclei of solid materials creates lattice defects which modify the properties of these solids, sometimes very significantly [64]. The details of the process vary significantly between different standardized materials and, therefore, must be explored experimentally. The book series entitled "Effects of Radiation on Nuclear Materials" published by the American Society for 
Testing of Materials (ASTM) as Special Technical Publications has a rich history, having evolved over the course of five decades starting as a symposium that has provided an international forum for the presentation of current research results, applications studies and open discussions on radiation effects in reactor pressure vessel steels (RPV). Thus, in this work, 20 ASTM STP books related to radiation effects on reactor pressure vessels have been reviewed along with other scientific literature to collect historical conclusions on the materials behavior of the materials specifications most used in the manufacture of RPV.

There are a number of considerations involving experimental details which should be kept in mind when the results of radiation damage experiments are evaluated [35]. A few obvious ones will be discussed below. First, it is important to remember the distinction between an in-pile test and a post-irradiation test. An in-pile test is one in which changes in properties are measured while the material is exposed to a reactor environment similar to the one in which it will eventually perform its design function; a post-irradiation test measures only residual changes which persist after the material is removed from the reactor environment [65]. To determine experimentally the value of the $\triangle R T_{D B T}$ and, therefore, the fracture toughness $\left(K_{I C}\right)$ of the irradiated material, monitoring capsules (specimens to check the condition of the material in the same service conditions of the vessel) are included in the vessel between the core and the wall. These capsules contain specimens of the vessel material, both welds and thermally affected zone and base material. The surveillance capsules are periodically removed in order to test the specimens, which allows to know in advance the state of the material that makes up the vessel. The capsules include tensile, Charpy impact and fracture toughness specimens, as well as the instrumentation necessary to monitor neutron flux and temperature. Consequently, Figure 4 provides the evolution trend of $K_{I C}$ after irradiation.

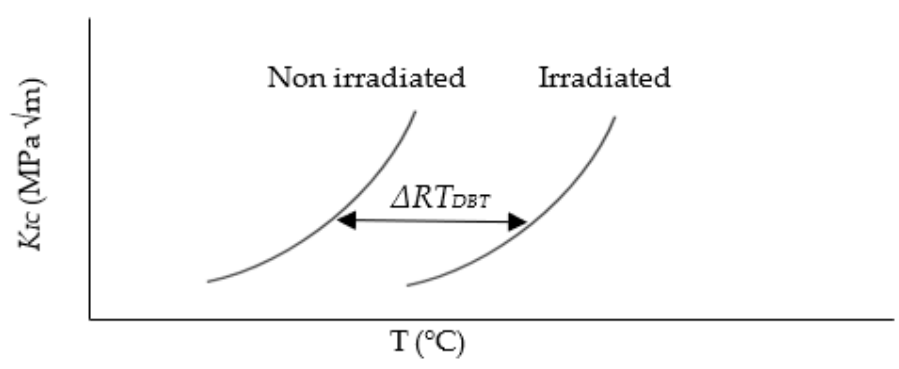

Figure 4. Fracture toughness variation due to irradiation.

According to the KTA 3201.2 [66] standard, the damage caused by neutron radiation must be taken into account when the neutron flux $(\phi)$ exceeds a value of $1 \times 10^{17} \mathrm{n} / \mathrm{cm}^{2}$. In order to quantify the degradation of materials, the monitoring programs according to the KTA 3203 [55] standard require the use of neutron flux intervals ranging from $\phi=1 \times 10^{19} \mathrm{n} / \mathrm{cm}^{2}$ to $\phi=5 \times 10^{19} \mathrm{n} / \mathrm{cm}^{2}$. Thus, Table 3 exhibits the most relevant findings from irradiation experiments on RPV metals using a $\phi$ greater than $1 \times 10^{17} \mathrm{n} / \mathrm{cm}^{2}$ according to the KTA 3201.2 requirement [66]. Table 3 provides the main conclusions from the analysis of the most relevant results from ASTM STP irradiation embrittlement experiments.

On the other hand, Table 4 reports the most relevant prediction models of ductile-tobrittle transition temperature shift due to irradiation embrittlement.

The first consolidated equation for estimating $\triangle R T_{D B T}$ was established in 1986 by Odette in the ASTM STP-909, being completed by the equation proposed by Miannay in 1990 (ASTM STP 1046). Cu role in embrittlement (and ductile to brittle transition temperature) was identified since the 1950s. Although the NUREG CR 6551 and ASTM E900-02 introduces mainly the influence of P wt.\% and a Bias term (in the case of ASTM E900-02) including the irradiation term, differences for usual testing conditions are not very substantial. Figure 5 illustrates the $\triangle R T_{D B T}$ as a function of $\mathrm{Cu}$ and $\mathrm{Ni}$ wt.\% content according to NUREG and E-900-02 models (for an irradiation time, $t_{i}<97,000 \mathrm{~h}$ ). 


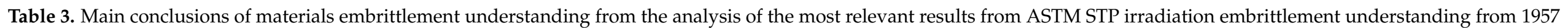
to 2014.

\begin{tabular}{|c|c|c|c|c|c|}
\hline \multirow{2}{*}{ Year } & \multirow{2}{*}{ Ref. ASTM } & \multirow{2}{*}{ Structural Materials } & \multicolumn{2}{|c|}{ Testing Conditions } & \multirow{2}{*}{ Highlighted Conclusions } \\
\hline & & & $\phi\left(\mathrm{n} / \mathrm{cm}^{2}\right)$ & $\mathrm{T}\left({ }^{\circ} \mathrm{C}\right)$ & \\
\hline \multirow{2}{*}{1957} & \multirow{2}{*}{ STP-208 [67] } & ASTM A-212B & $\begin{array}{l}1.0 \cdot 10^{19} \\
1.0 \cdot 10^{20}\end{array}$ & $\begin{array}{l}60 \\
93\end{array}$ & $\begin{array}{c}\Delta\left(U T S_{I}-U T S_{N-I}\right)=30.5 \%, \Delta\left(Y p_{I}-Y p_{N-I}\right)=7.7 \% \\
\Delta\left(U T S_{I}-U T S_{N-I}\right)=87.2 \%, \Delta\left(Y p_{I}-Y p_{N-I}\right)=29.5 \%\end{array}$ \\
\hline & & ASTM A-302B & $3.7 \cdot 10^{18}$ & $240-280$ & $\Delta\left(U T S_{I}-U T S_{N-I}\right)=10.9 \%, \Delta\left(Y p_{I}-Y p_{N-I}\right)=4.2 \%$ \\
\hline 1962 & STP-341 [68] & ASTM A-212B & $2 \cdot 10^{18}$ & 25 & No appreciable changes in the ductile-to-brittle transition temperature. \\
\hline 1967 & STP-426 [69] & ASTM A-212B/302B & $2 \cdot 10^{18}$ & 300 & $\Delta R T_{D B T}=18.33^{\circ} \mathrm{C}$. \\
\hline \multirow[t]{2}{*}{1970} & \multirow[t]{2}{*}{ STP-484 [70] } & A302B & $\begin{array}{l}8.0 \cdot 10^{18} \\
2.0 \cdot 10^{20}\end{array}$ & \multirow[t]{2}{*}{260} & $\begin{array}{c}\Delta\left(U T S_{I}-U T S_{N-I}\right)=7.61 \%, \Delta\left(Y p_{I}-Y p_{N-I}\right)=39.74 \% \\
\Delta\left(U T S_{I}-U T S_{N-I}\right)=31.42 \%, \Delta\left(Y p_{I}-Y p_{N-I}\right)=73.08 \%\end{array}$ \\
\hline & & A542 & $\begin{array}{l}6.0 \cdot 10^{18} \\
3.0 \cdot 10^{20}\end{array}$ & & $\begin{aligned} \Delta\left(U T S_{I}-U T S_{N-I}\right) & =10.24 \%, \Delta\left(Y p_{I}-Y p_{N-I}\right)=27.52 \% \\
\Delta\left(U T S_{I}-U T S_{N-I}\right) & =43.31 \%, \Delta\left(Y p_{I}-Y p_{N-I}\right)=66.97 \%\end{aligned}$ \\
\hline \multirow{2}{*}{1979} & \multirow{2}{*}{ STP-683 [71] } & A302B & $3.0 \cdot 10^{19}$ & \multirow{2}{*}{288} & $\Delta R T_{D B T}=55^{\circ} \mathrm{C}$ \\
\hline & & A533B & $5-7 \cdot 10^{19}$ & & $\Delta R T_{D B T}=12-35^{\circ} \mathrm{C}$ \\
\hline 1981 & STP-725 [72] & A533B & $10^{18}-10^{20}$ & & Embrittlement is maximized at $150^{\circ} \mathrm{C}$. \\
\hline \multirow{2}{*}{1983} & \multirow{2}{*}{ STP-819 [73] } & A533B & $1.2 \cdot 10^{19}$ & 290 & $\Delta R T_{D B T}=24^{\circ} \mathrm{C}$ \\
\hline & & A508-3 & $1.9 \cdot 10^{19}$ & 290 & $\Delta R T_{D B T}=27^{\circ} \mathrm{C}$ \\
\hline 1994 & STP-1175 [74] & A533-B & $0.7 \cdot 10^{18}$ & 280 & $\Delta R T_{D B T}=7-12{ }^{\circ} \mathrm{C}$. \\
\hline 1999 & STP 1325 [75] & A533-B & $4.0 \cdot 10^{23}$ & $\begin{array}{l}290 \\
350\end{array}$ & $\begin{array}{l}\Delta\left(Y p_{I}-Y p_{N-I}\right)=100 \mathrm{MPa} \text { for } \mathrm{Cu} \text { between } 0.5 \text { and } 0.9 \mathrm{wt} . \% . \\
\Delta\left(Y p_{I}-Y p_{N-I}\right)=180 \mathrm{MPa} \text { for } \mathrm{Cu} \text { between } 0.5 \text { and } 0.9 \mathrm{wt.} \% .\end{array}$ \\
\hline 2006 & STP 1475 [76] & A508-2/ A533-B & $10^{19}$ & 282 & $\begin{aligned} \text { A 508-2: } \Delta R T_{D B T} & =11 \% \text { greater after } 209000 \mathrm{~h}(24 \text { years }) \text { at about } 282^{\circ} \mathrm{C} . \\
\text { A533-B: } \Delta R T_{D B T} & =8 \% \text { greater after } 209000 \mathrm{~h}(24 \text { years }) \text { at about } 282{ }^{\circ} \mathrm{C} .\end{aligned}$ \\
\hline
\end{tabular}

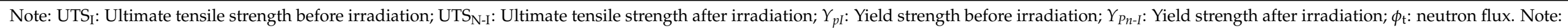
irradiation times up to $209,000 \mathrm{~h}$. 
Table 4. Review of most relevant prediction models of ductile-to-brittle transition temperature shift due to irradiation embrittlement.

\begin{tabular}{|c|c|c|}
\hline $\begin{array}{l}\text { ASTM Report or } \\
\text { Published Standard }\end{array}$ & Highlighted Contributions & \\
\hline \multirow{2}{*}{ STP-909 (1986) [77] } & Odette presented the equation: & \\
\hline & $\Delta R T_{D B T}\left({ }^{\circ} \mathrm{C}\right)=200 \cdot \mathrm{Cu} \cdot(1+1.38(\operatorname{erf}(0.3 \cdot \mathrm{Ni}-\mathrm{Cu}) / \mathrm{Cu})+1) \times\left(1-e^{(-\varphi / 0.11)}\right)^{1.36} \varphi^{18}$ & $(1)$ \\
\hline \multirow{2}{*}{ R.G. 1.99 Rev.2 (1988) [78] } & $\Delta R T_{D B T}=(C F) \times f^{(0.28-0.10 \log f)}$ & (2) \\
\hline & $\begin{array}{l}\text { where } C F \text { is the chemical factor provided by R.G. } 1.99 \mathrm{Rev.} 2 \text {, which is a function of } \mathrm{Cu} \\
\text { and Ni content in wt.\%; and } f \text { is the neutron flux in } \mathrm{n} / \mathrm{cm}^{2} \text {. }\end{array}$ & \\
\hline \multirow[b]{2}{*}{ STP-1046 (1990) [79] } & Miannay presented the equation: & \\
\hline & $\begin{array}{c}\Delta R T_{D B T}\left({ }^{\circ} \mathrm{C}\right)=10.98+316.4 \cdot(P-0.008)+225.29 \cdot(\mathrm{Cu}-0.08)+12.10 \cdot(\mathrm{Ni}-0.7)+248.31 \times \\
(\mathrm{Cu}-0.08) \cdot(\mathrm{Ni}-0.7)) \cdot \varphi^{0.70}\end{array}$ & (3) \\
\hline \multirow{6}{*}{ NUREG CR-6551 (1998) [80] } & $\Delta R T_{D B T}=S M D+C R P$ & $(4)$ \\
\hline & $S M D=A \exp \left[C_{T c} /\left(T_{c}+460\right)\right]\left[1+C_{P} P\right](\varphi t)^{\alpha}$ & $(5)$ \\
\hline & $C R P=B\left[1+C_{N i} N i \eta\right] F(C u) G(\varphi t)$ & $(6)$ \\
\hline & $\begin{array}{l}\text { To obtain the CRP contribution, it is necessary to calculate the } F(C u) \text { (Equation (6)) and } \\
\text { the } G(\varphi t) \text { (Equation }(7) \text { ) parameters. }\end{array}$ & \\
\hline & $F(C u)=\left\{0, C u \leq C u_{t h} ;\left(C u-C u_{t h}\right), C u>C u_{t h}\right\}$ & $(7)$ \\
\hline & $G(\varphi t)=\frac{1}{2}+\frac{1}{2} \tanh \left\{\left[\log \left(\varphi t+C_{t} t_{f}\right)-\mu\right] / \sigma\right\}$ & (8) \\
\hline \multirow{4}{*}{ ASTM E900-02 [81] } & $\Delta R T_{D B T}=S M D+C R P+$ Bias & (9) \\
\hline & The Bias term was introduced, & \\
\hline & Bias $=\left\{0, t_{i}<97,000 \mathrm{~h} ; 9.4, t_{i} \geq 97,000 \mathrm{~h}\right\}$ & (10) \\
\hline & where $t_{i}$ is the irradiation time & \\
\hline
\end{tabular}

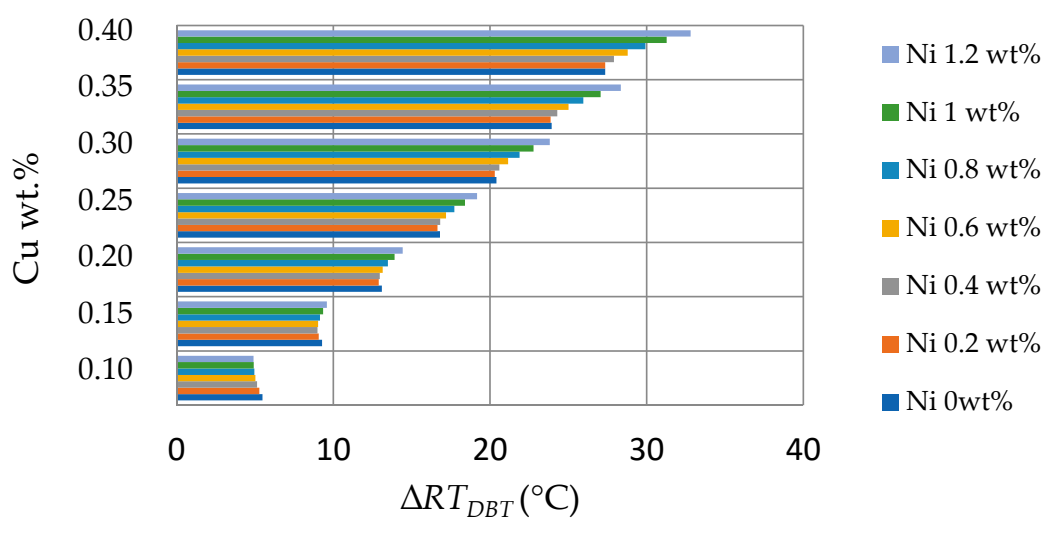

Figure 5. $\triangle R T_{D B T}$ vs. $\mathrm{Cu}$ and Ni wt.\% content according to NUREG and E-900-02 models.

According to NUREG and E-900-02 models, the $\triangle R T_{D B T}$ is always lower than $40{ }^{\circ} \mathrm{C}$ (as established by KTA 3203 [55] while the $\mathrm{Cu} w \mathrm{w} . \%$ is below $0.4 \%$ and the $\mathrm{Ni}$ wt.\% is below $1.2 \%$ ). This highlights that these theoretical models are less stringent than other experimental work that provides more stringent thresholds [51-54] according to information contained in Table 2.

The nuclear industry is a very conservative sector and, even nowadays, the model most consolidated and used is the U.S. NRC R.G. 1.99 Rev.2 because it is more stringent, meeting even the requirements of experimental works that established chemical composition restrictions for $\mathrm{Cu}$ and $\mathrm{Ni}$ [48-54]. Thus, Figure 6 provides the acceptable $\mathrm{Cu}$ and 
$\mathrm{Ni}$ wt.\% combination to contribute a $\triangle R T_{D B T}$ lower than the limit established by KTA 3203 [55].

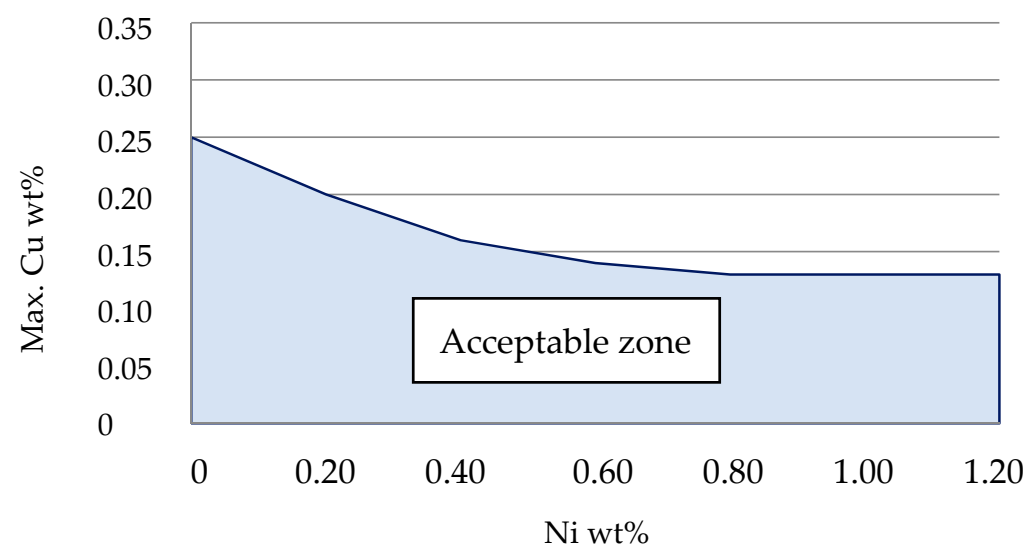

Figure 6. Maximum Cu wt.\% content as a function of the Ni wt.\% content according to R.G. 1.99 Rev.2 model and the maximum allowable $\Delta R T_{D B T}\left(40{ }^{\circ} \mathrm{C}\right)$ according to KTA 3203 [55].

Table 5 provides the highlighted findings reported in ASTM STP related to the influence of chemical composition in embrittlement and the establishment of thresholds and verifications of standardized limits.

Table 5. Highlighted findings reported in ASTM STP related to the influence of chemical composition in embrittlement and the establishment of thresholds and verifications of standardized limits.

\begin{tabular}{|c|c|}
\hline ASTM Report or Published Standard & Highlighted Findings \\
\hline STP-782 (1982) [82] & $\begin{array}{l}\text { The sensitivity to irradiation embrittlement depends on } \mathrm{Cu} \text { wt. } \% \text { contents from } 0.03 \text { to } \\
0.10 \mathrm{wt} . \% \text {, as well as on Ni contents for A508-2 and A508-3 and testing } 10^{18}-10^{20} \mathrm{n} / \mathrm{cm}^{2} \text {. }\end{array}$ \\
\hline STP-1170 (1993) [83] & $\begin{array}{l}\text { Amayev proposed that } \mathrm{P} \geq 0.02 \mathrm{wt} \% \text { negatively affects the mechanical properties of the } \\
\text { material. Mager [38] did not find dependence between neutron flux rates from } \\
\qquad \phi=2.5 \times 10^{18} \mathrm{n} / \mathrm{cm}^{2} \text { to } \phi=8.8 \times 10^{19} \mathrm{n} / \mathrm{cm}^{2} .\end{array}$ \\
\hline STP-1270 (1996) [84] & Odette presented a $\mathrm{Cu}$ limitation: 0.10 wt. $\%$ \\
\hline STP 1447 (2004) [85] & $\begin{array}{c}\text { The NRC draft correlation adds a term representing an additional shift if the steel has } \\
\text { been exposed to more than } 97,000 \mathrm{~h} \text { of high temperature. }\end{array}$ \\
\hline STP 1492 (2008) [86] & $\begin{array}{l}\text { The A533B steel plate with high content of } \mathrm{P} \text { exhibited significant hardening, as well as } \\
\text { grain boundary P segregation, and a large } \triangle R T_{D B T} \text { of } 230{ }^{\circ} \mathrm{C} \text { due to neutron irradiation } \\
\text { to a fluence of } 6.9 \cdot 10^{19} \mathrm{n} / \mathrm{cm}^{2} \text { and } \mathrm{E} \leq 1 \mathrm{MeV} \text { at } 290^{\circ} \mathrm{C} \text {. }\end{array}$ \\
\hline STP 1572 (2014) [87] & $\begin{array}{l}\text { Adequate safety margins of } \triangle R T_{D B T} \text { with respect to the German KTA 3201.2. standard } \\
\text { [66] curve were observed for all materials with } \mathrm{Cu} \leq 0.15 \% \text { and } \mathrm{Ni} \leq 1.1 \% \text { for which the } \\
\qquad \Delta R T_{D B T} \text { curve is valid. }\end{array}$ \\
\hline
\end{tabular}

In ASTM STP 782 in 1982, the first restrictions were proposed; however, Odette in ASM STP 1270, in 1996, established the most consolidated restriction for $\mathrm{Cu}(0.1 \%$ maximum wt.\%). Amayev in ASTM STP 1170 (1993) proposed that P content greater than $0.02 \mathrm{wt} . \%$ negatively affects the mechanical properties of the material.

\section{Results}

As the previous review of the historical research on the irradiation embrittlement of RPV ferritic steels stated, to improve materials performance, it is necessary to control the wt.\% content of several impurities $(\mathrm{Cu}, \mathrm{P}, \mathrm{V}$ and $\mathrm{Si})$ and the wt.\% content of some alloy elements such as Ni. Subsequently, in Section 3.1, an analysis of the evolution of technical restrictions in historical materials used in the RPV construction is performed. 


\subsection{Stage 3.-Analysis of the Evolution of Chemical Composition Restrictions in Historical Materials Used in RPV Manufacturing}

As previously mentioned, in this work, analysis of the main standardized requirements involved in the susceptibility increasing for irradiation embrittlement of the RPV materials used since the first reactors was performed. Table 6 presents the material designation, the chronology of use, the type and generation of reactor, the design code involved in the construction and information on whether $\mathrm{Cu}, \mathrm{Ni}$ and $\mathrm{P}$ were included in the standard.

Table 6. Historical materials used in PWR, design code and information on $\mathrm{Cu}, \mathrm{Ni}, \mathrm{P}$ requirements.

\begin{tabular}{|c|c|c|c|c|c|c|}
\hline Material & Chronology & Type and Generation of Reactor & Design Code & $\mathrm{Cu}$ & $\mathrm{Ni}$ & $\mathbf{P}$ \\
\hline ASTM A-302B (plate) & $1960 \mathrm{~s}$ & PWR 1st & & - & - & - \\
\hline ASTM A-212 B (plate) & 1960s (withdrawn 1967) & PWR 1st & ASME B\&PVC & - & - & $X$ \\
\hline ASTM A 543 B (plate) & $1960 \mathrm{~s}$ & PWR 1st & & - & $X$ & $X$ \\
\hline JIS G-3120 SQV2A (plate) & $1970 s-1980 s$ & PWR 2nd & & - & $X$ & $X$ \\
\hline JIS G-3204 SFVQ1A (forging) & $1980 \mathrm{~s}$ & PWR 2nd-3rd & JSME & - & $X$ & $X$ \\
\hline WWER 15Kh2MFA (forging) & $1970 s-1980 s$ & WWER-440 & & - & $X$ & $X$ \\
\hline WWER $15 \times 2$ MFA (forging) & $1970 s-1980 s$ & WWER-440 & Gosgortechnadzor & $X$ & $X$ & $X$ \\
\hline WWER 15Kh2MFAA (forging) & $1970 s-1980 s$ & WWER-440 & & $X$ & $X$ & $X$ \\
\hline ASME SA-533 Gr. B Cl.1 (plate) & $1980 \mathrm{~s}$ & PWR 2nd-3rd & & $X$ & $X$ & $X$ \\
\hline ASME SA-508 Grade 2 (forging) & $1980 \mathrm{~s}$ & PWR 2nd-3rd & ASME B\&PVC & $X$ & $X$ & $X$ \\
\hline ASME SA-508 Cl.3 (forging) & 1980s-present & PWR 2nd-4th; PHWR & & $X$ & $X$ & $X$ \\
\hline DIN 20MnMoNi55 (forging) & 1980s-present & PWR 2nd-4th; PBMR & & $X$ & $X$ & $X$ \\
\hline DIN 22NiMoCr37 (forging) & 1980s-present & PWR 2nd-4th & KTA & $X$ & $X$ & $X$ \\
\hline RCC 16MND5 (forging) & 1980s-present & PWR 2nd-4th & RCC-MR & $X$ & $X$ & $X$ \\
\hline ASTM A-336 Grade F22V (forging) & (present) & GT-MHR (General Atomics) & ASME B\&PVC & $X$ & $X$ & $X$ \\
\hline
\end{tabular}

Note: PWR: pressurized water reactor; PBMR: pebble bed modular reactor; PHWR: pressurized heavy water reactor; GT-.MHR: gas turbine modular helium reactor; WWER: water-cooled water-moderated power reactor. ASME B\&PVC: American Society of Mechanical Engineers Boiler \& Pressure Vessels Code, KTA-Kerntechnischer Ausschuss (German Nuclear Safety code), RCC-MR: French Nuclear Safety code; JSME: Japanese Society of Mechanical Engineers; Gosgortechnadzor: Russian Nuclear Safety code.

As shown in Table 6, in the earliest steps, no requirements for $\mathrm{Cu}, \mathrm{Ni}$ and $\mathrm{P}$ were included in the standards; in fact, the $\mathrm{Cu}$ requirement was not added until the 1970s.

For the analysis, Table 7 presents the main chemical requirements $(\mathrm{Cu}, \mathrm{P}, \mathrm{Ni}, \mathrm{Mn}$, $\mathrm{Mo}, \mathrm{Si}$ and $\mathrm{V}$ ) along with the maximum elongation $(E L)$ and the maximum $\sigma_{\mathrm{y}} / \mathrm{UTS}$ ratio (margin of safety against failure by plastic collapse).

Table 7 shows the main chemical and mechanical requirements analyzed in this work.

To study, overall, the evolution of the main requirements involved in the irradiation embrittlement susceptibility (i.e., $\mathrm{Cu}, \mathrm{P}$ and Ni), Figure 7 reports the change in the maximum allowable wt.\% of $\mathrm{Cu}, \mathrm{Ni}$ and $\mathrm{P}$.

On the other hand, Figure 8 shows the evolution of $(\mathrm{Cu}, \mathrm{Ni}$ and $\mathrm{P})$ restrictions in wt.\% for every origin of standard and technology.

The Si requirements for every generation of materials are very similar. Vanadium increases the susceptibility of the material to neutron irradiation embrittlement (Hawthorne) and it decreases the weldability of the steel. Figure 9 shows the Evolution of V restrictions.

As Figure 9 shows, the most consolidated and novel standardized materials show the minor levels of maximum allowable $\mathrm{V}$ wt.\%. Thus, the vanadium requirement has been evolving to demand lower maximum wt.\% values.

\subsection{Stage 4.-Application of R.G. 1.99 to Estimate $\triangle R T_{D B T}$ for the Historical and Recent Materials to Analyze the Effect of Requirements' Evolution}

The Regulatory Guide 1.99 Rev.2 proposes the most consolidated model for the calculation of the displacement of the ductile-brittle transition temperature as a function of the $\mathrm{Cu}$ and Ni content of the steel and the neutron flux [88]. This model is selected among the models included in Table 4 by Regulatory Guide (R.G.) 1.99 Rev.2 (1988) proposes a model for calculating the $\triangle R T_{D B T}$ shift depending on the $\mathrm{Cu}$ and $\mathrm{Ni}$ content and neutron flux, according to Equation (2) (given in Table 4). Figure 10 exhibits the $\triangle R T_{D B T}$ Matrix according to R.G. 1.99 Rev.2 (for neutron fluence of $1 \cdot 10^{19} \mathrm{n} / \mathrm{cm}^{2}$ ) for each analyzed mate- 
rial. The maximum allowable $\Delta R T_{D B T}$ established by KTA 3203 [55], $40{ }^{\circ} \mathrm{C}$, is used as an acceptance criterion.

Table 7. Chemical and mechanical requirements of analyzed materials.

\begin{tabular}{|c|c|c|c|c|c|c|c|}
\hline \multirow[b]{2}{*}{ RPV Material } & \multicolumn{5}{|c|}{ Chemical Requirements (Maximum wt.\%) } & \multicolumn{2}{|c|}{ Mechanical Requirements } \\
\hline & $\mathrm{Cu}$ & $\mathbf{P}$ & $\mathbf{N i}$ & Si & $\mathbf{V}$ & $\begin{array}{l}\text { Maximum Elongation } \\
(E L) \text { in } \%\end{array}$ & $\begin{array}{c}\text { Maximum } \\
\sigma_{y} / U T S\end{array}$ \\
\hline ASTM A 212B, & N.S. & 0.035 & N.S. & 0.30 & N.S. & 23 & 0.68 \\
\hline ASTM A 302B & N.S. & N.S. & N.S. & 0.40 & N.S. & 15 & 0.56 \\
\hline ASTM A 543 B & N.S. & 0.020 & 4.00 & 0.40 & N.S. & 18 & 0.56 \\
\hline ASME SA 533 Grade B Cl.1 & 0.12 & 0.015 & 0.73 & 0.45 & 0.06 & 18 & 0.56 \\
\hline JIS G 3204 SFVQ1A & N.S. & 0.035 & 0.70 & 0.30 & N.S. & 18 & 0.54 \\
\hline ASME SA 508 Grade 2 & 0.20 & 0.025 & 1.00 & 0.40 & 0.05 & 16 & 0.64 \\
\hline DIN 22NiMoCr37 & 0.11 & 0.025 & 1.00 & 0.35 & 0.05 & 16 & 0.64 \\
\hline ASME SA 508 Grade 3; & 0.20 & 0.025 & 1.00 & 0.40 & 0.05 & 16 & 0.64 \\
\hline DIN 20MnMoNi55 & 0.12 & 0.012 & 0.85 & 0.35 & 0.02 & 19 & 0.59 \\
\hline RCC 16 MND5 & 0.20 & 0.020 & $0-80$ & 0.30 & 0.02 & 20 & 0.66 \\
\hline JIS G 3204 SFVQ1A & N.S. & 0.025 & 1.00 & 0.40 & 0.05 & 18 & 0.72 \\
\hline ASTM A 336 Grade F22V & 0.20 & 0.015 & 0.25 & 0.10 & 0.35 & 20 & 0.60 \\
\hline WWER 15X2MF & 0.30 & 0.020 & 0.40 & 0.37 & 0.35 & 14 & 0.80 \\
\hline WWER 15Kh2MFA & N.S. & 0.025 & 0.40 & 0.37 & 0.35 & 14 & 0.80 \\
\hline WWER 15Kh2MFAA & 0.08 & 0.012 & 0.40 & 0.37 & 0.35 & 15 & 0.81 \\
\hline
\end{tabular}
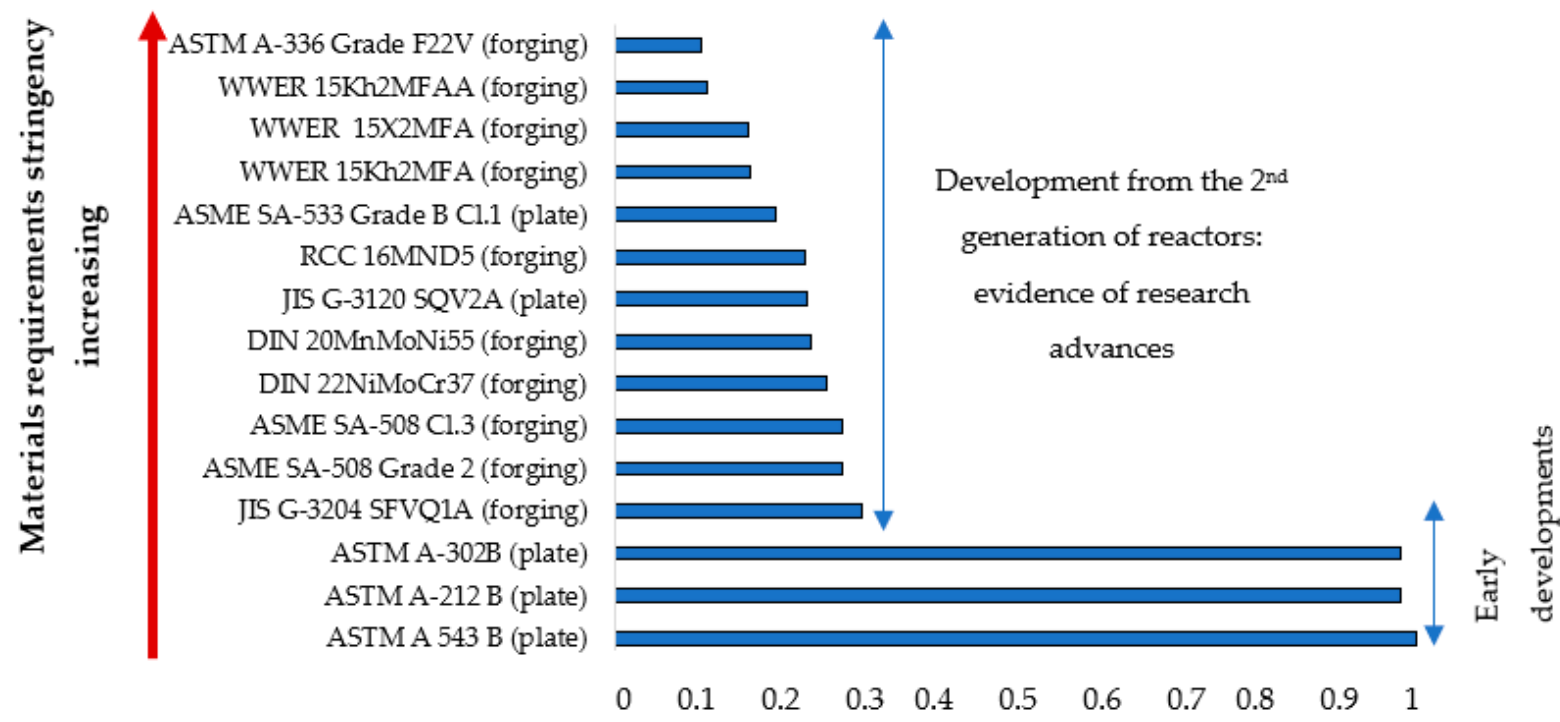

$\mathrm{Cu} w t \%+P w t \%+N i w t \%$ requirements

Figure 7. Evolution of restrictions on $\mathrm{Cu}, \mathrm{Ni}$ and $\mathrm{P}$ wt.\% contents.

WWER 15Kh2MFAA (used from the 1970s and 1980s; already in operation) ASME SA-533 Grade B Cl.1 (used in PWR 2nd-4th; already in operation), DIN 20MnMoNi55 and DIN 22NiMoCr37 (used in PWR 2nd-4th) and ASTM A-336 Grade F22V (current designs) provide a $\triangle R T_{D B T}$ shift lower than $40{ }^{\circ} \mathrm{C}$ (as stablished by KTA 3203).

Thus, the most consolidated options-those that show a reliable in-service behavior across decades-had been chosen by establishing more stringent restrictions related to pernicious elements such as $\mathrm{Cu}, \mathrm{P}, \mathrm{Ni}$ or $\mathrm{V}$. In addition, the latest standardized grades incorporated to the design codes have generally used the same conservative criterion, establishing safety thresholds related to the maximum content of the abovementioned alloy elements and impurities, considering, therefore, the most relevant scientific research advances in the field of irradiation embrittlement understanding. 


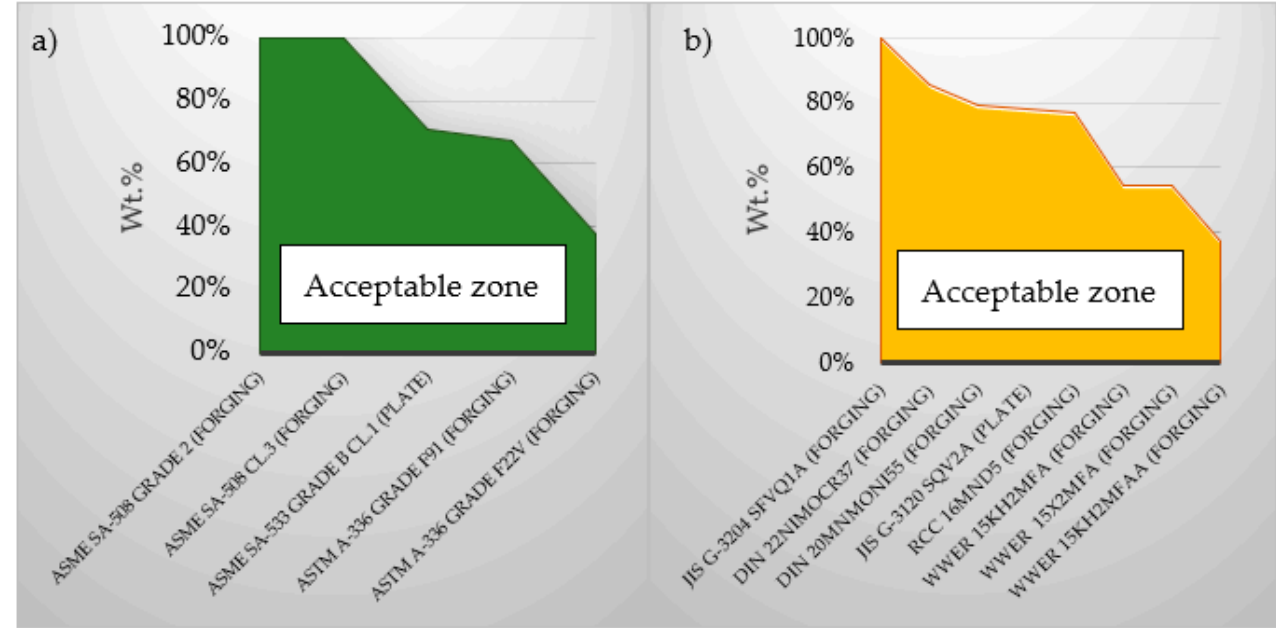

Figure 8. Evolution of restrictions: (a) American standardized RPV materials; (b) German, French, Russian and Japanese standardized RPV materials.

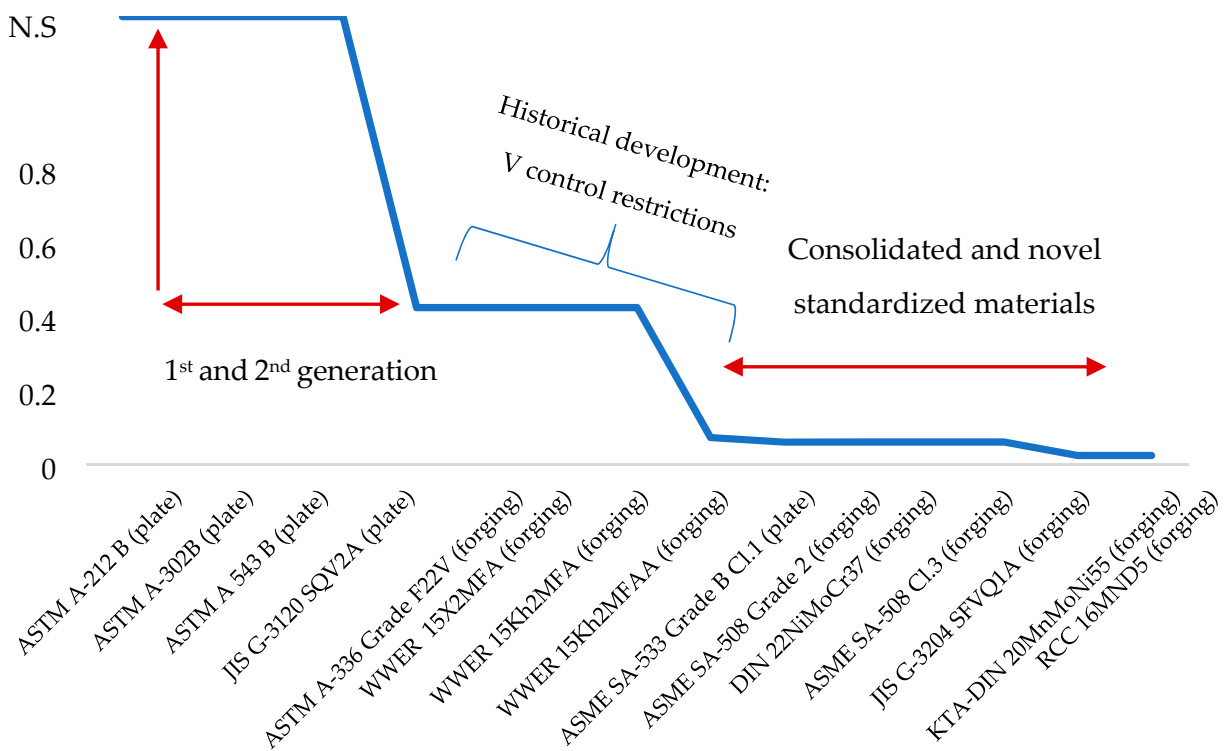

Figure 9. Evolution of vanadium restrictions.

\begin{tabular}{r|cccccccc|} 
Cu wt & \multicolumn{7}{c}{ Ni wt\% } \\
\% & $\mathbf{0}$ & $\mathbf{0 . 2}$ & $\mathbf{0 . 4}$ & $\mathbf{0 . 6}$ & $\mathbf{0 . 8}$ & $\mathbf{1}$ & $\mathbf{1 . 2}$ \\
$\mathbf{0 . 1 0}$ & 5.00 & 14.44 & $\mathbf{1 8 . 3 3}$ & 18.33 & $\mathbf{1 9 . 4 4}$ & $\mathbf{1 9 . 4 4}$ & 19.44 \\
$\mathbf{0 . 1 5}$ & 16.11 & 26.67 & 37.22 & 43.33 & 46.11 & 47.22 & 47.22 \\
$\mathbf{0 . 2 0}$ & 27.78 & $\mathbf{3 8 . 8 9}$ & 51.67 & 65.00 & 70.56 & 73.33 & 73.89 \\
$\mathbf{0 . 2 5}$ & 40.00 & 52.22 & 64.44 & 80.00 & 92.78 & 97.78 & 101.11 \\
$\mathbf{0 . 3 0}$ & 53.89 & 63.33 & 75.00 & 90.00 & 107.22 & 120.56 & 125.00 \\
$\mathbf{0 . 3 5}$ & 67.22 & 75.56 & 86.11 & 100.00 & 116.11 & 133.33 & 147.78 \\
$\mathbf{0 . 4 0}$ & 79.44 & 87.22 & 97.22 & 110.56 & 125.00 & 142.22 & 160.00
\end{tabular}

\begin{tabular}{|c|c|c|c|c|c|c|c|}
\hline \multicolumn{8}{|c|}{ Material and symbol } \\
\hline A-302B & & A-212 B & $\square$ & $\begin{array}{l}\text { A } 543 \\
\text { B }\end{array}$ & & $\begin{array}{c}\text { G- } \\
3120 \\
\text { sov2 }\end{array}$ & \\
\hline $\begin{array}{l}\text { G-3204 } \\
\text { SFVQ1A }\end{array}$ & 口 & $\begin{array}{l}15 \mathrm{Kh} 2 \mathrm{M} \\
\mathrm{FA}\end{array}$ & & $\begin{array}{l}15 \times 2 \\
\text { MFA }\end{array}$ & 四 & $\begin{array}{l}15 \mathrm{Kh} 2 \\
\text { MFA } \\
\text { A }\end{array}$ & \\
\hline $\begin{array}{l}\text { SA-533 } \\
\text { Gr. B } \\
\text { C.1 }\end{array}$ & & $\begin{array}{c}\text { SA-508 } \\
\text { Gr. } 2 \text { and } \\
\text { C..3 }\end{array}$ & $\square$ & $\begin{array}{c}20 \mathrm{Mn} \\
\mathrm{MoNi} \\
55\end{array}$ & $\square$ & $\begin{array}{c}22 \mathrm{Ni} \\
\mathrm{Mocr} \\
37\end{array}$ & \\
\hline $16 \mathrm{MND} 5$ & & $\begin{array}{l}\text { A-336 } \\
\text { Grade } \\
\text { F22V }\end{array}$ & & & & & \\
\hline
\end{tabular}

Figure 10. Ductile-to-brittle transition temperature shift $\left(\triangle R T_{D B T}\right)$ matrix according to R.G. 1.99 Rev.2 (for neutron fluence of $\left.1 \cdot 10^{19} \mathrm{n} / \mathrm{cm}^{2}\right)$. 
Elevated maximum elongation is desirable because the material becomes brittle when it is exposed to neutron flux [14]. Whereas, a lower $\sigma_{y} / U T S$ ratio is desirable for seismic resistance, since it implies greater energy absorption capacity before failure. Figure 11 presents $E L$ requirement (\%) and $\sigma_{y} / U T S$ ratio as an indicator of the materials toughness (energy absorbed by plastic deformation before break).
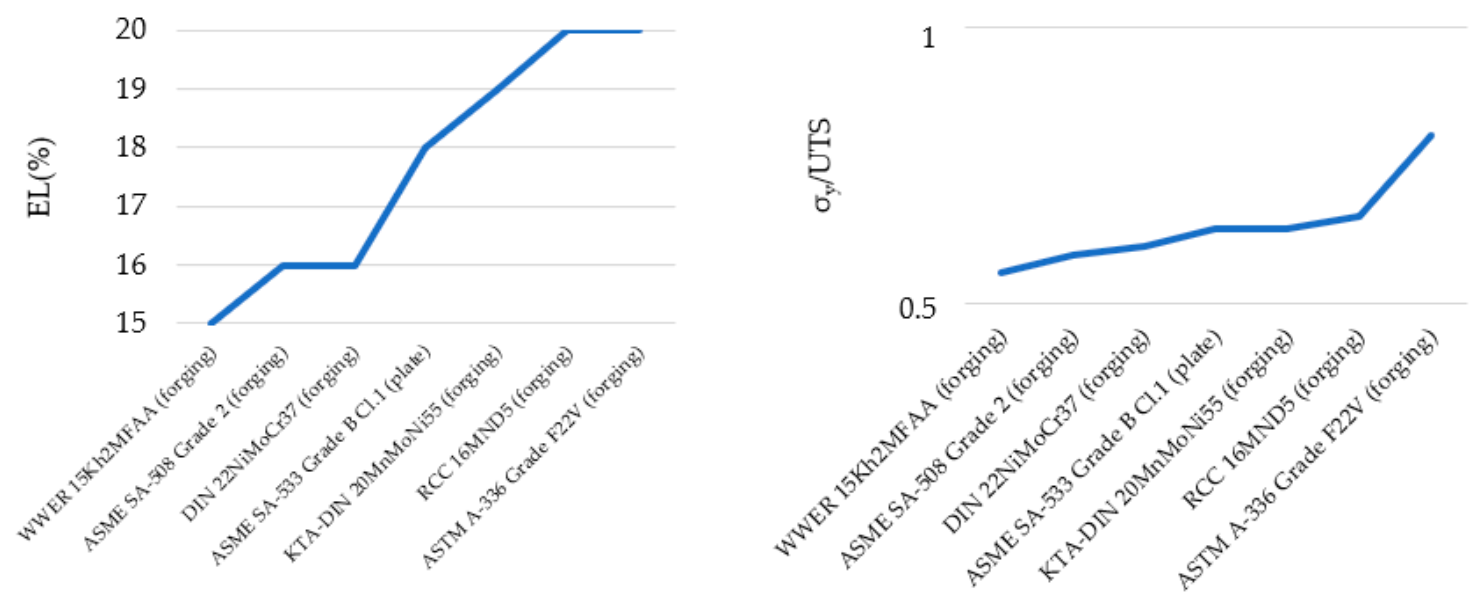

Figure 11. (a) Maximum elongation ( $E L_{\max }$ ) requirement (\%); (b) $\sigma_{y} / U T S$ ratio as an orientated indicator of the materials toughness (energy absorbed by plastic deformation before break).

Analyzing the trend for elongation and $\sigma_{y} /$ UTS ratio, it is observed that it is the same with respect to the materials evolution. A higher $\sigma_{y} / U T S$ ratio implies that the material absorbs less energy by plastic deformation, whereas a higher $E L$ implies greater ductility. Since a balance between $E L$ and $\sigma_{y} / U T S$ is desirable, a ductility-toughness ratio is defined (Equation (11)).

$$
D-T=\frac{E L \times U T S}{\sigma_{y}}
$$

Figure 12 provides the materials that exhibit a most balanced ductility-toughness ratio $(D-T)$, showing also the evolution of the ductility requirements (considered an adequate balance between ductility and toughness).

Ductility increasing for a suitable toughness (balanced behavior)

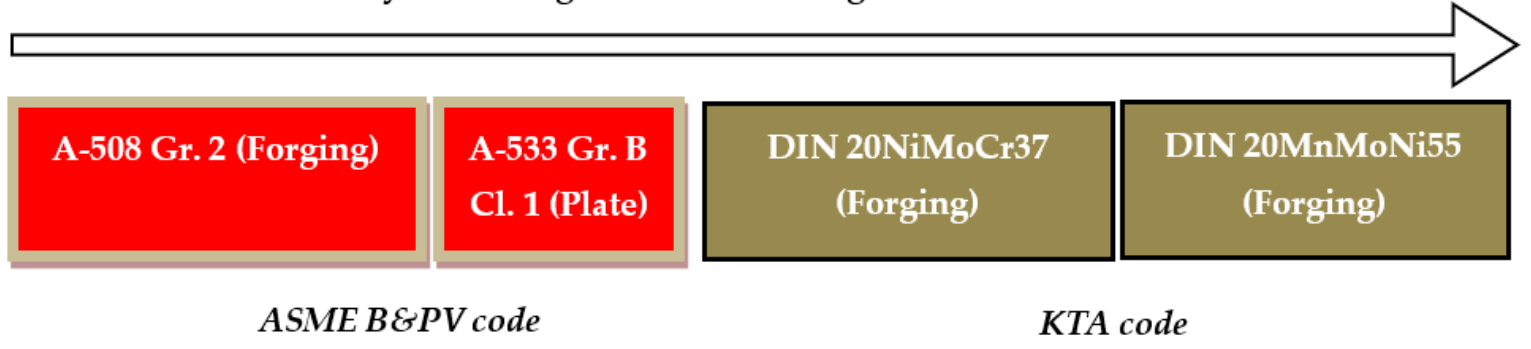

Figure 12. $D-T$ ratio evolution for the materials with a balanced relation between ductility and toughness.

Therefore, more central values are recommendable: i.e., the values exhibited by A-508 Gr. 2, A-533 Gr.B Cl.1, DIN 20NiMoCr37 and DIN 20MnMoNi55, these being the most consolidated standardized materials, developed in the 1980s but still used nowadays. All these specifications are the most consolidated and used in the manufacture of reactor pressure vessels. Therefore, the results confirm the fact that nuclear technology is in constant development, with safety as its fundamental pillar $[23,89,90]$.

The data presented in historical works about the influence of chemical composition, neutron flux and temperature in reactor operating conditions are still considered 
valid today, since these results have been verified through the investigation of materials from surveillance capsules removed from reactors that have been in operation for decades [40-43]. Consequently, the analyzed KTA (Germany) and ASME (USA) requirements are more stringent compared with the RCC-MR (France), Gosgortechnadzor and JSME (Japan) codes [91,92].

\section{Conclusions}

Nuclear energy enables many countries to ensure energy supply security and sustainable development as well as actively addressing environmental challenges. This work is a contribution to keep updated the technical heritage associated with movable and intangible goods related to nuclear power plants, and, to be more precise, the design and manufacturing codes of RPVs and their standardized material specifications which have not been thoroughly studied in scientific and technical literature. The accidents and reactor pressurevessel failures (e.g., Three Mile Island in USA, Chernobyl in Ukraine and Fukushima in Japan) have often caused the establishment of more severe safety specifications containing more stringent technological requirements.

In this work, a novel analysis of the historical modifications and advances in materials properties research and their associated standardized restrictions for RPVs was performed. More than 80 historical research works were analyzed in this study, evaluating the historical conclusions and their impact on design and manufacturing codes and, therefore, on their standardized materials requirements.

The novelty of this new approach lies in the idea of integrating a review and analysis of the historical research results on irradiation embrittlement understanding to evaluate the impact on standards and safety guides. The study is based on a selection of key scientific publications about the influence of chemical composition on the mechanical behavior of materials after irradiation. Thus, the major conclusions resulting from this work are as follows:

- Steels with low levels of impurities are recommended for the current light water RPV steels and for the new-generation nuclear systems. However, it is recommended to review historical scientific advances related to the understanding of radiation embrittlement and the key factors involved in this phenomenon. This review allows one to analyze the evolution of the essential technological requirements and how they were integrated in the codes, standards and standardized specifications. Consequently, this is the rich technical heritage provided by the scientific research and the technical advancement that provides for safe and sustainable nuclear power generation now and in the future.

- According to NUREG and E-900-02 models, the $\triangle R T_{D B T}$ is always lower than $40{ }^{\circ} \mathrm{C}$ (as established by KTA 3203 [55]) when the Cu wt.\% is below $0.4 \%$ and the $\mathrm{Ni}$ wt. $\%$ is below $1.2 \%$. This highlights that these theoretical models are less stringent than other experimental works that provide more stringent thresholds [51-54], according to information contained in Table 2. The nuclear industry is very conservative and, even nowadays, the model most consolidated and used is the U.S. NRC R.G. 1.99 Rev. 2 because it is more stringent, meeting the requirements of several experimental works [51-54].

- The results obtained by applying the analysis based on the consolidated U.S: NRC R.G. 1.99 Rev. 2 model allow for the definition of the best material options that correspond to some of the most widely used material specifications, such as WWER 15Kh2MFAA (used from the 1970s and 1980s; already in operation) ASME SA-533 Grade B Cl.1 (used in PWR 2nd-4th; already in operation), DIN 20MnMoNi55 and DIN 22NiMoCr37 (used in PWR 2nd-4th), as well as ASTM A-336 Grade F22V (current designs). This confirms a trend of improving the standards for improving nuclear safety.

- Finally, using a novel ductility-toughness ratio, the materials that exbibit the most balanced ductility-toughness ratio are: SA-508 Gr. 2, SA-533 Gr.B Cl.1, DIN 20NiMoCr37 and DIN 20MnMoNi55. 
- Thus, in view of the results obtained, it can be concluded that the best options correspond to recently developed or well-established specifications used in the design of pressurized water reactors. These assessments endorse the fact that nuclear technology is in a state of continual development, with safety being its fundamental pillar.

In the future, new research related to the analysis of technical heritage from the evolution of material requirements for other clean and sustainable power generation technologies will be performed.

Author Contributions: Conceptualization, A.R.-P. and A.M.C.; Formal analysis, A.R.-P., M.F. and A.M.C.; Funding acquisition, A.R.-P. and A.M.C.; Investigation, A.R.-P. and M.F.; Methodology, A.R.-P. and A.M.C.; Project administration, A.R.-P.; Resources, A.R.-P., M.F. and A.M.C.; Supervision, A.R.-P. and A.M.C.; Validation, A.R.-P., M.F., J.K. and A.M.C.; Writing-original draft, A.R.-P.; Writingreview and editing, A.R.-P., M.F., J.K. and A.M.C. All authors have read and agreed to the published version of the manuscript.

Funding: This work is part of the activities included in the transfer contract of research results with reference 2020-CTINV-0053. In addition, this work has also been partially funded by the Annual Grants Call of the E.T.S.I. Industriales of UNED through the projects of references 2021-ICF07 and 2021-ICF08, as well as by the Innovation Teaching Project of the GID2016-28 focused on "Reliability and Advanced Failure Prognosis in industrial applications applied to the teaching of Materials Technology and Processing".

Acknowledgments: This work has been realized in the framework of the activities of the Research Group of the UNED "Industrial Production and Manufacturing Engineering (IPME)" and the Industrial Research Group "Advanced Failure Prognosis for Engineering Applications". Authors also want to acknowledge Industrial Heritage Working Group of the Manufacturing Engineering Society (MES-SIF).

Conflicts of Interest: The authors declare no conflict of interest.

\section{References}

1. Raj, B.; Vijayalakshmi, M.; Rao, P.R.V.; Rao, K.B.S. Challenges in Materials Research for Sustainable Nuclear Energy. MRS Bull. 2008, 33, 327-337. [CrossRef]

2. Wang, C.-N.; Su, C.-C.; Nguyen, V.T. Nuclear Power Plant Location Selection in Vietnam under Fuzzy Environment Conditions. Symmetry 2018, 10, 548. [CrossRef]

3. Serp, J.; Poinssot, C.; Bourg, S. Assessment of the Anticipated Environmental Footprint of Future Nuclear Energy Systems. Evidence of the Beneficial Effect of Extensive Recycling. Energies 2017, 10, 1445. [CrossRef]

4. Merk, B.; Litskevich, D.; Whittle, K.R.; Bankhead, M.; Taylor, R.J.; Mathers, D.; Mathers, D. On a Long Term Strategy for the Success of Nuclear Power. Energies 2017, 10, 867. [CrossRef]

5. Chu, S.; Arun, M. Opportunities and challenges for a sustainable energy future. Nature 2012, 488, 294-303. [CrossRef]

6. Lee, K.-H.; Kim, M.-G.; Lee, J.I.; Lee, P.-S. Recent Advances in Ocean Nuclear Power Plants. Energies 2015, 8, 11470-11492. [CrossRef]

7. Goldberg, D.M.; Hong, S. Minimizing the Risks of Highway Transport of Hazardous Materials. Sustainability 2019, 11, 6300. [CrossRef]

8. Dempsey, L.; Forsberg, C.; Dolan, T.J. Electricity production. In Molten Salt Reactors and Thorium Energy; Woodhead Publishing: Duxford, UK, 2017; pp. 13-28.

9. McDonald, C.F. Power conversion system considerations for a high efficiency small modular nuclear gas turbine combined cycle power plant concept (NGTCC). Appl. Therm. Eng. 2014, 73, 82-103. [CrossRef]

10. Di Ronco, A.; Giacobbo, F.; Lomonaco, G.; Lorenzi, S.; Wang, X.; Cammi, A. Preliminary Analysis and Design of the Energy Conversion System for the Molten Salt Fast Reactor. Sustainability 2020, 12, 10497. [CrossRef]

11. Rodríguez-Prieto, A.; Camacho, A.M.; Sebastián, M.A. Quantitative analysis of prediction models of hot cracking in stainless steels using standardized requirements. Sädhanā 2017, 42, 2147-2155. [CrossRef]

12. Merayo, D.; Rodríguez-Prieto, Á.; Camacho, A.M. Analytical and numerical study for selecting polymeric matrix composites intended to nuclear applications. Proc. Inst. Mech. Eng. Part L 2019, 233, 2072-2083. [CrossRef]

13. Rodríguez-Prieto, A. Análisis de Requisitos Tecnológicos de Materiales Especificados en Normativas Reguladas y su Repercusión Sobre la Fabricación de Recipientes Especiales Para la Industria Nuclear. Ph.D. Thesis, Universidad Nacional de Educación a Distancia, Madrid, Spain, 2014.

14. Rodríguez-Prieto, A.; Camacho, A.M.; Sebastián, M.A. Materials selection criteria for nuclear power applications: A decision algorithm. JOM 2016, 68, 496-506. [CrossRef] 
15. IAEA TECDOC-1442. Guidelines for Prediction of Irradiation Embrittlement of Operating WWER-440 Reactor Pressure Vessels; International Atomic Energy Agency Publications: Vienna, Austria, 2005; pp. 1-76.

16. Zinkle, S.J.; Busby, J.T. Structural materials for fission \& fusion energy. Mater. Today 2009, 12, 12-19. [CrossRef]

17. Rodríguez-Prieto, A.; Camacho, A.M.; Sebastián, M.A. Value analysis to optimize the manufacturing code selection process in the nuclear industry. In Proceedings of the 21th International Congress on Project Management and Engineering, Spain, 12-14 July 2017; AEIPRO-IPMA: Cadiz, Spain, 2017; pp. 721-729.

18. Rodríguez-Prieto, A.; Camacho, A.M.; Sebastián, M.A. Evaluation method for pressure vessel manufacturing codes: The in-fluence of ASME unit conversion. Int. J. Mater. Prod. Technol. 2017, 54, 259-274. [CrossRef]

19. Rodríguez-Prieto, A.; Camacho, A.M.; Merayo, D.; Sebastián, M.A. An educational software to reinforce the comprehensive learning of materials selection. Comput. Appl. Eng. Educ. 2018, 26, 125-140. [CrossRef]

20. Odette, G.R. Recent progress in developing and qualifying nanostructured ferritic alloys for advanced fission and fusion ap-plications. JOM 2014, 66, 2427-2441. [CrossRef]

21. Hosemann, P.; Frazer, D.; Fratoni, M.; Bolind, A.; Ashby, M. Materials selection for nuclear applications: Challenges and opportunities. Scr. Mater. 2018, 143, 181-187. [CrossRef]

22. Rodríguez-Prieto, A. Evaluación cuantitativa del riesgo de fallos en servicio como herramienta para la gestión de la integridad de materiales en centrales nucleares. In Proceedings of the 45 Reunión Anual de la Sociedad Nuclear Española, Vigo, Spain, 23-28 September 2019; SNE: Madrid, Spain, 2019; pp. 1-7.

23. Rodríguez-Prieto, A.; Camacho, A.M.; Sebastián, M.A. Selection of candidate materials for reactor pressure vessels using irra-diation embrittlement prediction models and a stringency level methodology. Proc. Inst. Mech. Eng. Part L 2019, 233, 965-976.

24. DOE/NE-0088. The History of Nuclear Energy; Office of Nuclear Energy, Science and Technology: Washington DC, USA, 2006 ; p. 19.

25. Fischer, D. History of the International Atomic Energy Agency: The First forty Years; International Atomic Energy Agency Publications: Vienna, Austria, 1997; p. 550.

26. GOV/INF/2017/12-GC(61)/INF/8. International Status and Prospects of Nuclear Power 2017; International Atomic Energy Agency Publications: Vienna, Austria, 2017.

27. NUREG/CR-5750. Rates of Initiating Events of US Nuclear Power Plants; U.S. Nuclear Regulatory Commission: Washington, DC, USA, 1998; p. 320.

28. Murakami, K.; Sekimura, N.; Iwai, T.; Abe, H. Heterogeneity of ion irradiation-induced hardening in A533B reactor pressure vessel model alloys. J. Nucl. Sci. Technol. 2015, 53, 1-6. [CrossRef]

29. IAEA NP-T-3.11. Integrity of Reactor Pressure Vessels in Nuclear Power Plants: Assessment of Irradiation Embrittlement Effects in Reactor Pressure Vessel Steels; International Atomic Energy Agency Publications: Vienna, Austria, 2009.

30. Seitz, F. Radiation effects in solids. Phys. Today 1952, 5, 6. [CrossRef]

31. Trampus, P. Reactor Pressure Vessel Integrity in Light of the Evolution of Materials Science and Engineering. Mater. Sci. Forum 2005, 2005, 287-292. [CrossRef]

32. Seitz, F. On the Disordering of Solids by Action of Fast Massive Particles. In Crystal Growth, Discussions of the Faraday Society; Faraday Society: London, UK, 1949; pp. 271-282.

33. Seitz, F.; Koehler, J.S. The theory of lattice displacements produced during irradiation. In Proceedings of the International Conference on the Peaceful Uses of Atomic Energy, Geneva, Switzerland, 8-20 August 1955; pp. 1-6.

34. Charlesby, A.; Hancock, N.; Sansom, H. Effect of atomic-pile radiation on the elastic modulus of an austenitic steel. J. Nucl. Energy 1954, 1, 264-273. [CrossRef]

35. Wilson, J.C.; Berggren, R.G. Effect of neutron irradiation in steel. Proc. Am. Soc. Testing Mats. 1955, 5, 1-19.

36. Porter, L.F. Radiation effects on steels. ASTM STP 1969, 276, 147-160.

37. Kangilaski, M. The Effects of Neutron Irradiation on Structural Materials; Battelle Memorial Institute Publications: Columbus, OH, USA, 1967; p. 253.

38. Mager, T.R. Report on utilization of reactor pressure surveillance data in support of aging management. ASTM STP 1993, 1170, 87-98.

39. Pachur, D. Apparent Embrittlement Saturation and Radiation Mechanisms of Reactor Pressure Vessel Steels. ASTM STP 1981, 725, 5-19. [CrossRef]

40. English, C.; Hyde, J. Radiation damage of reactor pressure vessels steels. In Comprenhensive Nuclear Materials; Konings, R.J., Ed.; Elsevier: New York, NY, USA, 2012; Volume 4, pp. 151-180.

41. Soneda, N.; Dohi, K.; Nishida, K.; Nomoto, A.; Iwasaki, M.; Tsuno, S.; Akiyama, T.; Watanabe, S.; Ohta, T. Flux effect on neutron irradiation embrittlement of Reactor Pressure Vessel steels irradiated to high fluences. In Proceedings of the International Symposium on Contribution of Materials Investigations to Improve the Safety and Performance of LWRs, Avignon, France, 26-30 September 2011; pp. 1-9.

42. IAEA-TECDOC-1230. Reference Manual on the IAEA JRQ Correlation Monitor Steel for Irradiation Damage Studies; International Atomic Energy Agency Publications: Vienna, Austria, 2001; pp. 1-36.

43. Serrano, M.; Hernández, M. Programas de investigación sobre fragilización por irradiación de los aceros de vasija. An. Mecánica Electr. 2008, 5, 42-47.

44. Ballesteros, A.; Ahlstrand, R.; Bruynooghe, C.; Chernobaeva, A.; Kevorkyan, Y.; Erak, D.; Zurko, D. Irradiation temperature, flux and spectrum effects. Prog. Nucl. Energy 2011, 53, 756-759. [CrossRef] 
45. Ballesteros, A.; Ahlstrand, R.; Bruynooghe, C.; von Estorff, U.; Debarberis, L. The role of pressure vessel embrittlement in the long term operation of nuclear power plants", Section Engineering (II). In Proceedings of the 38th Annual Meeting Spanish Nuclear Society, Cáceres, Spain, 17-19 October 2012; SNE: Cáceres, Spain, 2012.

46. Rodríguez-Prieto, A.; Camacho, A.M.; Sebastián, M.A. Multicriteria materials selection for extreme operating conditions based on a multiobjective analysis of irradiation embrittlement and hot cracking prediction models. Int. J. Mech. Mater. Des. 2018, 14, 617-634. [CrossRef]

47. Kobayashi, S.; Yamamoto, T.; Klingensmith, D.; Odette, G.; Kikuchi, H.; Kamada, Y. Magnetic evaluation of irradiation hardening in A533B reactor pressure vessel steels: Magnetic hysteresis measurements and the model analysis. J. Nucl. Mater. 2012, 422, 158-162. [CrossRef]

48. Odette, G.; Lucas, G.; Klingensmith, R. The Influence of Metallurgical Variables on the Temperature Dependence of Irradiation Hardening in Pressure Vessel Steels. In Proceedings of the 17th International Symposium on effects of radiation on materials, Sun Valley, ID, USA, 20-23 June 1996; American Society for Testing and Materials: West Conshohocken, PA, USA, 1996; pp. 606-622.

49. Odette, G.R.; Lucas, G.; Wirth, B.; Liu, C. Current understanding of the effects of environmental and irradiation variables on RPV embrittlement. In Proceedings of the 24th Water Reactor Safety Information Meeting, Bethesda, MD, USA, 21-23 October 1997; Nuclear Regulatory Commission: Washington, DC, USA; Volume 2, pp. 1-23.

50. Nagay, Y.; Tang, Z.; Hassegawa, M.; Kanai, T.; Saneyasu, M. Irradiation-Induced Cu aggregations in Fe: An origin of embrittlement of reactor pressure vessel steels. Phys. Rev. B Condens. Matter. 2001, 63, 1-5. [CrossRef]

51. Yamamoto, T.; Klingensmith, D. On the effect of dose rate on irradiation hardening of RPV steels. Philos. Mag. 2005, 85, 779-797. [CrossRef]

52. Petrequin, P.; Soulat, P.; Houssin, B. Effect of residual elements and Nickel on the sensitivity to irradiation embrittlement of SA 508 CL.3 pressure vessel steel and weld. In Irradiation Embrittlement Thermal Annealing and Surveillance of Reactor Pressure Vessels; Steele, L.E., Ed.; International Atomic Energy Agency Publications: Vienna, Austria, 1979; Volume 79, pp. 195-200.

53. Stofanak, R.; Poskie, T.; Li, Y.; Wire, G. Irradiation damage behaviour of low alloy steel wrought and weld materials. In Proceedings of the 6th International Symposium on Environmental Degradation of Materials in Nuclear Power Systems-Water Reactors, San Diego, CA, USA, 1-5 August 1993; pp. 757-763.

54. Nikolaeva, A.; Nikolaev, Y.; Krjoikov, A. The contribution of grain boundary effects to low-Alloy steel irradiation embrittle-ment. J. Nucl. Mater. 1994, 218, 85-93. [CrossRef]

55. KTA 3203. Monitoring the Radiation Embrittlement of Material of the Reactor Pressure Vessel of Light Water Reactors; Nuclear Safety Standards Commission (KTA): Salzgitter, Germany, 2017; pp. 1-18.

56. Amayev, A.D.; Kryukov, A.M.; Sokolov, M.A. Radiation embrittlement of nuclear reactor pressure vessels steels: An interna-tional review. ASTM STP 1993, 1170, 369-379.

57. Rodríguez-Prieto, A.; Camacho, A.M.; Sebastián, M.A.; Yanguas-Gil, A. Computer-aided sensitivity analysis of a multicriteria decision-making methodology for the evaluation of materials requirements stringency in nuclear components manufacturing. Proc. Inst. Mech. Eng. L. 2019, 233, 2094-2107. [CrossRef]

58. Barr, W. The Fracture of Metals; Institution of Metallurgists: London, UK, 1950.

59. Pickering, F.B.; Gladman, T. Metallurgical Developments in Carbon Steels; Iron and Steel Institute: London, UK, 1963.

60. Hawthorne, J.R. Significance of selected residual elements to the radiation sensitivity of steels. Nucl. Technol. 1982, 59, 440-455. [CrossRef]

61. De Garmo, E.P.; Black, J.T.; Kohser, R.A. Materials and Processes in Manufacturing, 13th ed.; John Wyley \& Sons: Hoboken, NJ, USA, $2019 ;$ p. 896.

62. Odette, G.R.; Lucas, G.E. Recent progress in understanding reactor pressure vessel embrittlement. Radiat. Eff. Defect. S. 1998, 144, 189-231. [CrossRef]

63. Gordon, G.M.; Klepfer, H.H. Engineering Significance of Ferrite Grain Size on the Radiation Sensitivity of Pressure Vessel Steels. ASTM STP 1967, 426, 48-66.

64. Nordlund, K.; Zinkle, S.J.; Sand, A.E.; Granberg, F.; Averback, R.S.; Stoller, R.E.; Suzudo, T.; Malerba, L.; Banhart, F.; Weber, W.J.; et al. Primary radiation damage: A review of current understanding and models. J. Nucl. Mater. 2018, 512, 450-479. [CrossRef]

65. Castleman, L.S. Survey of the Effects of Neutron Bombardment on Structural Materials. ASTM STP 1957, 208, $108-118$.

66. KTA 3201.2. Components of the Reactor Coolant Pressure Boundary of Light Water Reactors-Part 2: Design and Analysis; Nuclear Safety Standards Commission (KTA): Salzgitter, Germany, 2017; pp. 1-162.

67. ASTM STP 208. Radiation Effects on Materials, American Society for Testing and Materials; American Society for Testing and Materials: West Conshohocken, PA, USA, 1957; p. 271.

68. ASTM STP 341. Radiation Effects on Metals and Neutron Dosimetry; American Society for Testing and Materials: West Con-shohocken, PA, USA, 1963; p. 415.

69. ASTM STP 426. Effects of Radiation on Structural Metals; American Society for Testing and Materials: West Conshohocken, PA, USA, 1967; p. 706.

70. ASTM STP 484. Irradiation Effects on Structural Alloys for Nuclear Reactor Applications; American Society for Testing and Mate-rials: West Conshohocken, PA, USA, 1970; p. 570.

71. ASTM STP 683. Effects of Radiation on Structural Materials; American Society for Testing and Materials: West Conshohocken, PA, USA, 1979; p. 675. 
72. ASTM STP 725. Effects of Radiation on Materials; American Society for Testing and Materials: West Conshohocken, PA, USA, 1981; p. 759.

73. ASTM STP 819. Radiation Embrittlement and Surveillance of Nuclear Reactor Pressure Vessels: An International Study; American Society for Testing and Materials: West Conshohocken, PA, USA, 1983; p. 221.

74. ASTM STP 1175. Effects of Radiation on Materials; American Society for Testing and Materials: West Conshohocken, PA USA, 1994; p. 1319.

75. ASTM STP 1325. Effects of Radiation on Materials; American Society for Testing and Materials: West Conshohocken, PA, USA, 1999; p. 1120.

76. ASTM STP 1475. Effects of Radiation on Materials; American Society for Testing and Materials: West Conshohocken, PA, USA, 2006; p. 406.

77. ASTM STP 909. Radiation Embrittlement of Nuclear Reactor Pressure Vessel Steels: An International Review; American Society for Testing and Materials: West Conshohocken, PA, USA, 1986; p. 297.

78. R.G 1.99 Rev.2. Radiation Embrittlement of Reactor Vessel Materials; Nuclear Regulatory Commission (NRC): Washington, DC, USA, 1988; pp. 1-9.

79. ASTM STP 1046. Effects of Radiation on Materials; American Society for Testing and Materials: West Conshohocken, PA, USA, $1990 ;$ p. 672.

80. NUREG/CR-6551. Improved Embrittlement Correlations for Reactor Pressure Vessel Steels; Nuclear Regulatory Commission (NRC): Washington, DC, USA, 1998; p. 134.

81. ASTM E900. Standard Guide for Predicting Radiation-Induced Transition Temperature Shift in Reactor Vessel Materials; American Society for Testing and Materials: West Conshohocken, PA, USA, 2002; pp. 1-5.

82. ASTM STP-782. Effects of Radiation on Materials; American Society for Testing and Materials: West Conshohocken, PA, USA, $1982 ;$ p. 1219.

83. ASTM STP-1170. Radiation Embrittlement of Nuclear Reactor Pressure Vessel Steels: An International Review; American Society for Testing and Materials: West Conshohocken, PA, USA, 1993; p. 399.

84. ASTM STP-1270. Effects of Radiation on Materials; American Society for Testing and Materials: West Conshohocken, PA, USA, 1996; p. 1161.

85. ASTM STP 1447. Effects of Radiation on Materials; American Society for Testing and Materials: West Conshohocken, PA, USA, $2004 ;$ p. 758.

86. ASTM STP 1492. Effects of Radiation on Materials; American Society for Testing and Materials: West Conshohocken, PA, USA, 2008; p. 240.

87. ASTM STP 1572. Effects of Radiation on Nuclear Materials; American Society for Testing and Materials: West Conshohocken, PA, USA, 2014; p. 178.

88. Rodríguez-Prieto, A. Fragilización por irradiación neutrónica de la vasija: Algunas consideraciones para la selección de materiales. In Proceedings of the 42 Reunión Anual de la Sociedad Nuclear Española, Santander, Spain, 28-30 September 2016; SNE: Madrid, Spain; pp. $1-8$.

89. Wang, J.; Dailey, R.; Guo, Z.; Zhou, Y.; Humrickhouse, P.; Corradini, M.L. Accident tolerant fuels (FeCrAl Cladding \& Coating) performance analysis in Boiling Water Reactor (BWR) by the MELCOR 1.8.6 UDGC. Nucl. Eng. Des. 2021, 371, 110974. [CrossRef]

90. Wang, J.; Yeom, H.; Humrickhouse, P.; Sridharan, K.; Corradini, M. Effectiveness of Cr-Coated Zr-Alloy Clad in Delaying Fuel Degradation for a PWR During a Station Blackout Event. Nucl. Technol. 2020, 206, 467-477. [CrossRef]

91. Rodríguez-Prieto, A.; Camacho, A.M.; Sebastián, M.A. New decision methodology for selecting manufacturing codes of nuclear reactor pressure-vessels. In Proceedings of the Annals of DAAAM for 2015 and Proceedings of the 26th DAAAM International Symposium, Zadar, Croatia, 18-25 October 2015; DAAAM International: Vienna, Austria; pp. 693-698.

92. Rodríguez-Prieto, A.; Camacho, A.M.; Sebastián, M.A. Consideraciones técnicas acerca de los programas regulados para la vigilancia de las propiedades de aceros de vasija en reactores nucleares. Ind. Química 2016, 33, 76-83. 